\title{
Ramisyllis kingghidorahi n. sp., a new branching annelid from Japan
}

\author{
M. Teresa Aguado ${ }^{1}$ (1) - Guillermo Ponz-Segrelles ${ }^{2}$ (D) - Christopher J. Glasby ${ }^{3}$ (1) $\cdot$ Rannyele P. Ribeiro ${ }^{4,5}$ (D) \\ Mayuko Nakamura $^{6} \cdot$ Kohei Oguchi $^{6,7} \cdot$ Akihito Omori $^{8} \cdot$ Hisanori Kohtsuka $^{6} \cdot$ Christian Fischer $^{1} \cdot$ Yuji Ise $^{9}$. \\ Naoto Jimi ${ }^{10} \cdot$ Toru Miura $^{6}$
}

Received: 27 July 2021 / Accepted: 18 November 2021 / Published online: 19 January 2022

(c) The Author(s) 2022, corrected publication 2022

\begin{abstract}
Among over 20,000 species of Annelida, only two branching species with a highly modified body-pattern are known until now: the Syllidae Syllis ramosa McIntosh, 1879, and Ramisyllis multicaudata Glasby et al. (Zoological Journal of the Linnean Society, 164, 481-497, 2012). Both have unusual ramified bodies with one head and multiple branches and live inside the canals of host sponges. Using an integrative approach (combining morphology, internal anatomy, ecology, phylogeny, genetic divergence, and the complete mitochondrial genome), we describe a new branching species from Japan, Ramisyllis kingghidorahi n. sp., inhabiting an undescribed species of Petrosia (Porifera: Demospongiae) from shallow waters. We compare the new species with its closest relative, R. multicaudata; emend the diagnosis of Ramisyllis; and discuss previous reports of $S$. ramosa. This study suggests a much higher diversity of branching syllids than currently known. Finally, we discuss possible explanations for the feeding behaviour in the new species in relation to its highly ciliated wall of the digestive tubes (especially at the distal branches and anus), and provide a hypothesis for the evolution of branching body patterns as the result of an adaptation to the host sponge labyrinthic canal system.
\end{abstract}

Keywords Mitochondrial genome $\cdot$ Phylogenetics $\cdot$ Sponge $\cdot$ Syllidae $\cdot$ Symbiosis $\cdot$ Morphology $\cdot$ Anatomy $\cdot$ Ecology

M. Teresa Aguado

aguadomolina@uni-goettingen.de

1 Biodiversitätsmuseum, Animal Evolution \& Biodiversity, Georg-August-Universität Göttingen, Göttingen 37073, Germany

2 Departamento de Biología, Facultad de Ciencias, Universidad Autónoma de Madrid, Madrid 28049, Spain

3 Museum and Art Gallery of the Northern Territory, PO Box 4646, NT, Darwin 0801, Australia

4 Washington University in St. Louis, MO, St. Louis 63130, USA

5 Marine Biological Laboratory, MA, Wood Hole, 02543, USA

6 Misaki Marine Biological Station, School of Science, The University of Tokyo, Misaki, Miura, Kanagawa 238-0225, Japan

7 The National Institute of Advanced Industrial Science and Technology (AIST), Ibaraki, Tsukuba 305-8566, Japan

8 Marine Biological Station, Sado Island Center for Ecological Sustainability, Niigata University, 87 Tassha, Sado, Niigata 952-2135, Japan

9 Sesoko Station, Tropical Biosphere Research Center, University of the Ryukyus, 3422 Sesoko, Motobu-cho, Okinawa, 905-0227, Japan

10 Sugashima Marine Biological Laboratory, Toba, Sugashima 517-0004, Japan

\section{Introduction}

In 1879, McIntosh published the description of a "remarkable branched Syllid," Syllis ramosa, collected during the Challenger Expedition, one of the most significant natural history expeditions from the nineteenth century. The worms were found inside the hexactinellid sponge Crateromorpha meyeri (Gray, 1872) at $175 \mathrm{~m}$ deep near Cebu, in the Philippines. In relation to their lateral branches, McIntosh (1879) said: "the body of the annelid appears to have a furor for budding laterally, terminally, and wherever a broken surface occurs," which represented the first instance of an annelid species described with a randomly branching asymmetrical body. Some years later, in the complete report of marine annelids collected during the expedition, McIntosh (1885) described the same specimen of $S$. ramosa, together with another one found inside $C$. meyeri at $250 \mathrm{~m}$ deep close to the Kai Islands (Indonesia) in the Arafura Sea. Living specimens were found 10 years later by Oka (1895) (inside C. meyeri in Japan, around $25 \mathrm{~km}$ south of Misaki, between 550 and $730 \mathrm{~m}$ deep) and Izuka (1912) (in the "gastral cavity and adjacent parts" of Crateromorpha meyeri rugosa Ijima, 1898 in Sagami Bay at 180 m deep and in Suruga 
Bay at $165 \mathrm{~m}$ deep, both in Japan). Later, another finding of a branching annelid from a distant geographic area (the northern Red Sea) was attributed to $S$. ramosa by Crossland (1933). However, it was found inside a small, fragile 10-mm diameter unidentified siliceous sponge attached to a dead coral [Lobophyllia corymbosa (Forsskål, 1775)] at $1.8 \mathrm{~m}$ deep and, unfortunately, no drawings or detailed descriptions were provided. Then, it was not until Read (2001) that another report of $S$. ramosa surfaced, this time from a specimen of Crateromorpha about $600 \mathrm{~mm}$ long found at $1000 \mathrm{~m}$ deep in the Tasman Sea of New Zealand. Unfortunately, the head was not found and no details about the chaetae were provided. Finally, Imajima identified as $S$. ramosa one specimen from Sagami Bay, found in 2005 at $36-50 \mathrm{~m}$ and deposited in the National Museum of Nature and Science of Tokyo (collection code: NSMT-Pol S; Catalogue number: 1568).

The second known branching species, Ramisyllis multicaudata Glasby et al., 2012, was described from the coastal shallows of Darwin, Northern Australia (Glasby et al., 2012). This study demonstrated notable differences in biology and morphology between this species and S. ramosa and analysed its phylogenetic relationships inside Syllidae. Ramisyllis multicaudata shares with $S$. ramosa a randomly branching asymmetrical body and its way of living inside the labyrinthic internal canals of sponges, but differs (except for the Red Sea and Imajima's 2005 Sagami Bay reports of $S$. ramosa) in the host sponge (Petrosia vs. Crateromorpha), depth (0-20 m vs. 100-1000 m deep), and key morphological and anatomical details. Both species reproduce by schizogamy, forming gamete-bearing posterior segments that develop typical stolon features like eyes and sensory appendages. Once formed, these stolons are detached from the stocks to swim freely in the water column, where spawning occurs, while the stocks regenerate the posterior end.

Combining different mitochondrial and nuclear genes, Aguado et al. (2015a, b) found that $R$. multicaudata was nested in a clade containing all Syllinae reproducing by gemmiparity [i.e., stolons being developed simultaneously from newly developed segments according to Franke (1999) and San Martín and Aguado (2014)]. The clade was informally named as "the ribbon clade" because most of its members show flattened bodies. Within it, $R$. multicaudata was the sister group of a clade with species of Trypanobia. The postembryonic addition of segments (typical of many annelids), together with the regenerative abilities of syllids and its ability to produce several simultaneous newly formed segments during gemmiparity, may be at the evolutionary basis of the development of a branching body in $R$. multicaudata (Aguado et al., 2015a, b). The complete mitochondrial genomes of $R$. multicaudata and Trypanobia cryptica Aguado et al. (2015b), showed a gene order considerably different to the ground pattern of Syllidae (Aguado et al., 2015a), the latter being similar to the putative ground pattern of Pleistoannelida (Aguado et al., 2016).
The present study describes a third species of branching syllid, the second within Ramisyllis, living inside an undescribed species of Petrosia found in shallow waters at Sado Island (Japan). We provide a detailed morphological study, a phylogenetic analysis including several mitochondrial and nuclear genes, genetic distance analyses, and the complete mitochondrial genome. We discuss the possible existence of other branching species, which may coexist in Japanese waters, and possible feeding strategies. Finally, we provide a hypothesis for the evolution of branching body patterns as an adaptation to live inside the labyrinthic canals system of their host sponges.

\section{Materials and methods}

\section{Collection and morphological analyses}

The specimens were collected on 1 October 2019 at Shukunegi Point (Sado Island, Japan, 37 $48^{\prime} 17.1^{\prime \prime} \mathrm{N}$, $138^{\circ} 14^{\prime} 25.1^{\prime \prime E}$ ) (Fig. 1). Collecting permits were obtained from the Ogi branch of the Sado fishery cooperative by the authors belonging to the Sado Marine Biological Station (SMBS) of The Niigata University. Twenty-five specimens of Petrosia with their symbionts were collected by SCUBA at 10-15 m deep (Online Resource 1). The habitat and sponges were photographed with an underwater camera (TG-5, Olympus). Each sponge was cut at its base with a diving knife, placed in a plastic zip bag containing sea water, brought to the SMBS (Fig. 1), and placed in trays with constantly running sea water, except five complete specimens which were directly preserved in formalin and later transferred into 100\% ethanol. During the following four days, nineteen specimens were carefully dissected following Glasby et al. (2012). The remaining complete sponges were brought to Misaki Marine Biological Station (MMBS) of The University of Tokyo and placed in tanks with running sea water, where they survived for 3 months; three more sponges were dissected during this period. The worms were preserved in $100 \%$ ethanol, RNA later, methanol, formalin, paraformaldehyde (PFA) 4\%, and phosphate-buffered saline pH 7.4 (PBS) for different purposes (Online Resource 1).

Morphological observations and photographs of branches, details of parapodia, stolons, and anterior ends were made using an Olympus SZX7 stereomicroscope and an Olympus BX53 compound microscope with attached cameras. For scanning electron microscopy (SEM), the specimens fixed in PFA 4\% in PBS, were treated with $\mathrm{OsO}_{4}$ for 20 min, rinsed with $\mathrm{ddH}_{2} \mathrm{O}$ (five times), dehydrated in a graded ethanol series $(20 \%, 50 \%, 70 \%, 90 \% 100 \%, 20$ min each), critical point dried (in a BALZERS CPD 030), mounted on stubs, gold coated (with a BALZERS SCD 050), and observed and 


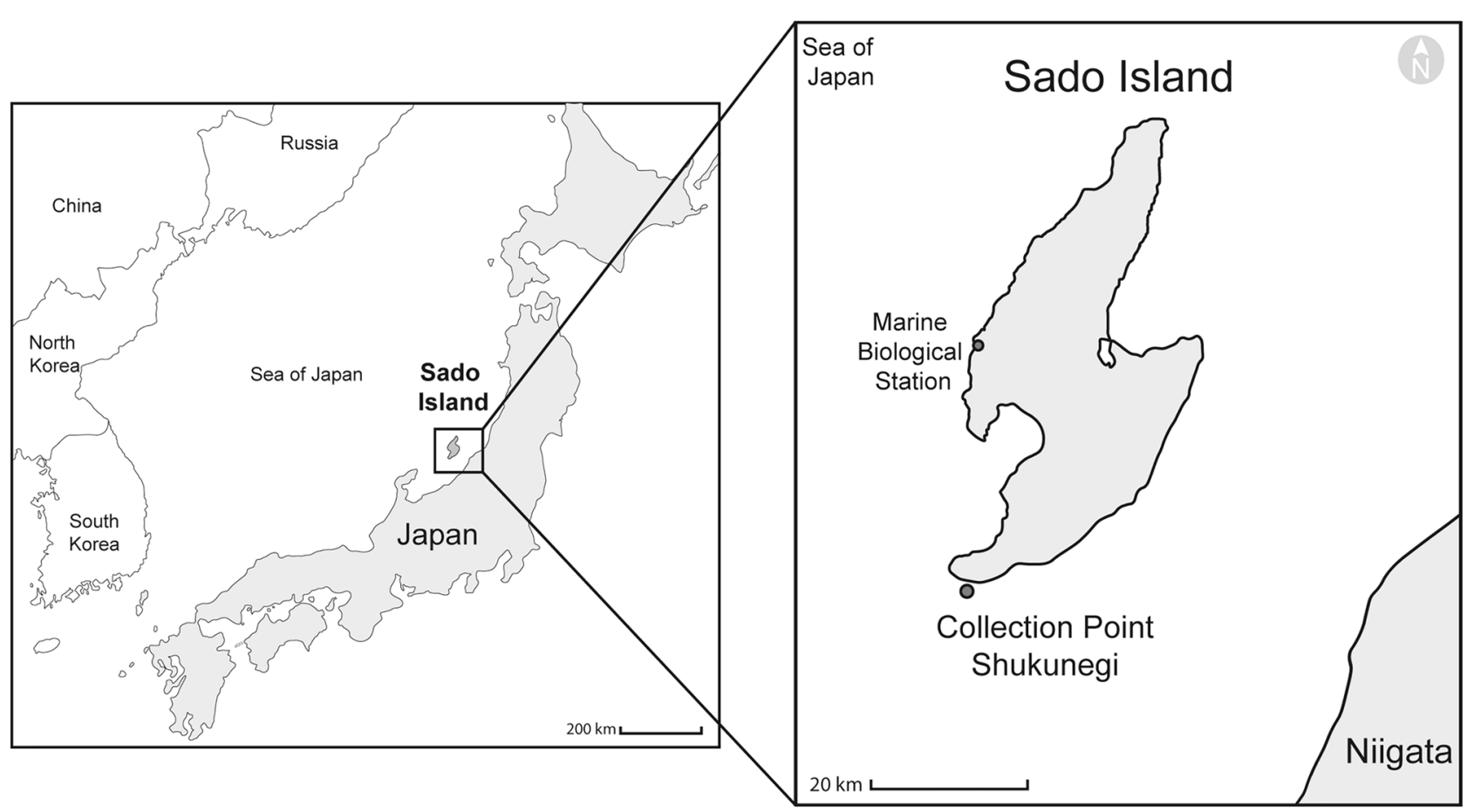

Fig. 1 Sampling area in the Sea of Japan. Shukunegi, Sado Island, Japan

photographed with a SEM FEI Quanta 250 FEG. Figures were prepared with Adobe Photoshop CC (Adobe).

The arrangement of the nervous-system was assessed by immunological staining using monoclonal antibodies against the general neuronal marker acetylated $\alpha$-tubulin protein. Cell density and muscle disposition was assessed by staining with DAPI (4',6-diamidino-2-phenylindole) and rhodamine-labelled phalloidin. Specimens fixed in $4 \%$ PFA in PBS were washed in 1 XPBT $(0.3 \% \mathrm{v} / \mathrm{v}$ Triton X-100 in $1 \mathrm{XPBS})$, transferred to BBT (0.2\% Bovine Serum Albumin in PBT), blocked for 30 min with NGS/BBT ( $2 \% \mathrm{v} / \mathrm{v}$ Normal Goat Serum in BBT), incubated overnight at $4{ }^{\circ} \mathrm{C}$ with the primary antibody (monoclonal Mouse anti-acetylated alphatubulin from AdipoGen, Seoul, Korea) in NGS/BBT (1:100 dilution), again washed in BBT and blocked with NGS/BBT, incubated in BBT (dilution 1:200) with the fluorescentconjugated secondary antibodies (Alexa Flour 488 Goat anti-Mouse IgG, Invitrogen, Eugene, OR), washed in PBT, stained with rhodamine-labelled phalloidin (5 unit/mL PBT) or DAPI ( $5 \mu \mathrm{g} / \mathrm{mL}$ PBT), washed again with PBT, mounted with anti-fade solution VECTOR Shield (Vector Laboratories, Inc., Burlingame, CA), and observed using a confocal laser scanning microscope (FV3000, OLYMPUS, Tokyo). Image stacks were processed using Imaris 9.3 (Bitplane) and images were edited using Photoshop CC.

Type and voucher specimens have been deposited at the Biodiversitätsmuseum Georg-August-Universität Göttingen (ZMUG), the Museo Nacional de Ciencias Naturales de Madrid
(MNCNM), and the National Museum of Nature and Science of Tokyo (NSMT).

\section{DNA extraction, amplification, and sequencing}

Seven specimens fixed in $90-100 \%$ ethanol and RNAlater were sequenced, together with seven specimens of $R$. multicaudata from Darwin (Australia) collected in 2009, 2015, and 2017 and fixed in RNAlater (Glasby et al., 2012; PonzSegrelles et al., 2021) (Table 1). Adequately fixed material is still not available for $S$. ramosa. Hence, this species has not been included in the phylogenetic and genetic distance analyses.

Genomic DNA was extracted using standard protocols from six of the seven specimens from each location and used to sequence the mitochondrial genes cytochrome oxidase subunit $1(\mathrm{COI})$ and $16 \mathrm{~S}$, the nuclear genes $18 \mathrm{~S}$ and $28 \mathrm{~S}$, and the nuclear marker ITS2. The remaining specimens from Japan (holotype, SA1; Table 1) and Darwin (RM7, Table 1) were used for genome and transcriptome sequencing, respectively (see methods below).

Single markers were obtained by polymerase chain reaction (PCR). Amplification consisted of an initial denaturation at $96{ }^{\circ} \mathrm{C}$ for $1-2 \mathrm{~min}$, followed by $35-40$ cycles of denaturation at $95{ }^{\circ} \mathrm{C}$ for $30 \mathrm{~s}$ to $1 \mathrm{~min}$, annealing at $42-51{ }^{\circ} \mathrm{C}$ for $30 \mathrm{~s}$ and extension at $72{ }^{\circ} \mathrm{C}$ for $1-1.5 \mathrm{~min}$. At the end of the reaction, a final extension of 8-10 min at $72{ }^{\circ} \mathrm{C}$ was performed. $\mathrm{COI}$ and $16 \mathrm{~S}$ sequences were 
Table 1 Terminals included genes, GenBank accession numbers, and sampling localities. Sequences obtained for this study in bold

\begin{tabular}{|c|c|c|c|c|c|c|}
\hline Species & $18 \mathrm{~S}$ & $16 \mathrm{~S}$ & $\mathrm{COI}$ & $28 \mathrm{~S}$ & IST2 & Locality \\
\hline Ramisyllis multicaudata_RM1 & KR604716 & KR534502 & KR534502 & OK172175 & - & Darwin, NT, Australia \\
\hline Ramisyllis multicaudata_RM2 & OK169527 & OK169536 & OK166784 & OK172172 & - & Darwin, NT, Australia \\
\hline Ramisyllis multicaudata_RM3 & OK169528 & OK169538 & OK166786 & OK172176 & - & Darwin, NT, Australia \\
\hline Ramisyllis multicaudata_RM4 & OK169525 & OK169540 & OK166787 & OK172173 & - & Darwin, NT, Australia \\
\hline Ramisyllis multicaudata_RM5 & OK169526 & OK169537 & OK166783 & OK172174 & - & Darwin, NT, Australia \\
\hline Ramisyllis multicaudata_RM6 & OK169524 & OK169539 & OK166785 & OK172178 & - & Darwin, NT, Australia \\
\hline Ramisyllis multicaudata_RM7 & OK169523 & OK169541 & OK166788 & OK172177 & OK169529 & Darwin, NT, Australia \\
\hline Ramisyllis kingghidorahi_SA1 & OK169520 & MZ571475 & MZ571475 & OK172171 & OK169531 & Sado Island, Niigata, Japan \\
\hline Ramisyllis kingghidorahi_SA9 & OK169517 & OK169511 & OK156179 & OK172167 & OK169535 & Sado Island, Niigata, Japan \\
\hline Ramisyllis kingghidorahi_SA28 & OK169519 & OK169514 & OK156177 & OK172168 & OK169534 & Sado Island, Niigata, Japan \\
\hline Ramisyllis kingghidorahi_SA46 & OK169518 & OK169515 & OK156180 & OK172165 & - & Sado Island, Niigata, Japan \\
\hline Ramisyllis kingghidorahi_SA53 & OK169521 & OK169513 & OK156178 & OK172166 & OK169530 & Sado Island, Niigata, Japan \\
\hline Ramisyllis kingghidorahi_SA87 & OK169516 & OK169510 & OK156181 & OK172169 & OK169532 & Sado Island, Niigata, Japan \\
\hline Ramisyllis kingghidorahi_SA88 & OK169522 & OK169512 & - & OK172170 & OK169533 & Sado Island, Niigata, Japan \\
\hline Alcyonosyllis phili & KM277824 & KM277822 & KM277827 & - & - & Kimberley, WA, Australia \\
\hline Branchiosyllis exilis 1 & JF903583 & JF903692 & - & - & - & Darwin, NT, Australia \\
\hline Eurysyllis sp. A1 & - & - & KX084930 & KX084804 & - & Balayan Bay, Luzon Island, Philippines \\
\hline Eurysyllis sp. B1 & KX084850 & KX084862 & KX084943 & - & - & $\begin{array}{l}\text { Sombrero Island, Balayan Bay, Luzon } \\
\text { Island, Philippines }\end{array}$ \\
\hline Eurysyllis tuberculata 4 & KX084853 & KX084925 & KX084932 & KX084806 & - & Balayan Bay, Luzon Island, Philippines \\
\hline Eurysyllis tuberculata 3 & KX084851 & - & KX084934 & KX084807 & - & San Vicente do Mar, Galicia, Spain \\
\hline Eurysyllis tuberculata 1 & JF903594 & - & JF903787 & - & - & Shark Bay, WA, Australia \\
\hline Eurysyllis tuberculata 2 & EF123833 & - & EF123748 & - & - & Banyuls-sur-mer, France \\
\hline Eusyllis blomstrandi & EF123887 & EF123788 & EF123749 & - & - & Kaldbak, Faroe Islands \\
\hline Haplosyllis spongicola & EF123837 & EF123791 & EF123751 & - & - & Banyuls-sur-mer, France \\
\hline Megasyllis inflata & JF913966 & JF913954 & JF903776 & - & - & Port Jackson, NSW, Australia \\
\hline Parahaplosyllis brevicirra & - & JF903706 & JF903784 & - & - & Port Jackson, NSW, Australia \\
\hline Parahaplosyllis kumpol & - & KX084922 & KX084966 & - & - & Cavalli Islands, New Zealand \\
\hline Paraopisthosyllis alternocirra & JF903623 & JF903707 & JF903786 & - & - & Rottnest Is., WA, Australia \\
\hline Plakosyllis sp. & KX084855 & - & KX084933 & KX084808 & - & El Nido, Palawan Island, Philippines \\
\hline Pseudosyllis brevipennis 1 & - & KX084917 & KX084969 & - & - & Port de la Selva, Girona, Spain \\
\hline Pseudosyllis brevipennis 2 & EF123878 & EF123816 & EF123785 & - & - & Port de la Selva, Girona, Spain \\
\hline Syllis amica & KX084858 & KX084924 & KX084927 & KX280928 & - & Puerto Colera, Girona, Spain \\
\hline Typosyllis anoculata & DQ790098 & - & - & DQ790071 & - & GenBank \\
\hline Syllis columbretensis & KX084845 & KX084860 & KX084928 & KX280925 & - & Cap de Creus, Girona, Spain \\
\hline Syllis compacta & EF123846 & EF123806 & EF123772 & - & - & Altea, Alicante, Spain \\
\hline Syllis gracilis complex $\mathrm{Sg} 1$ & KX281029 & KX280967 & KX281005 & KX280926 & - & $\begin{array}{l}\text { “Koala point,” Balayan Bay, Luzon } \\
\text { Island, Philippines }\end{array}$ \\
\hline Syllis gracilis complex Sg5 & KX281030 & KX280966 & KX281007 & KX280927 & - & $\begin{array}{l}\text { "Koala point,” Balayan Bay, Luzon } \\
\text { Island, Philippines }\end{array}$ \\
\hline Syllis gracilis complex $\mathrm{Sg} 10$ & KX281044 & KX280937 & KX280980 & KX280920 & - & El Nido, Palawan Island, Philippines \\
\hline Syllis gracilis complex $\mathrm{Sg} 9$ & KX281039 & KX280936 & KX280979 & KX280919 & - & $\begin{array}{l}\text { "Mainif point" between Balayan Bay and } \\
\text { Batangas Bay, Luzon Is, Philippines }\end{array}$ \\
\hline Syllis hyalina & KX281051 & - & KX280977 & KX280931 & - & $\begin{array}{l}\text { Sombrero Island, Balayan Bay, Luzon } \\
\text { Island, Philippines }\end{array}$ \\
\hline Syllis lutea & JF903663 & JF903736 & JF903785 & - & - & Shark Bay, WA, Australia \\
\hline Syllis malaquini & MN533981 & MN533980 & MN533982 & - & - & Aquarium Madrid, Spain \\
\hline Syllis marugani & EF123863 & EF123812 & EF123780 & - & - & Manazuru Peninsula, Japan \\
\hline Syllis picta & KX281028 & KX280968 & KX281009 & KX280924 & - & $\begin{array}{l}\text { “Twin Rocks," El Nido, Palawan Island, } \\
\text { Philippines }\end{array}$ \\
\hline Syllis pulvinata & KX281050 & KX280969 & KX280976 & KX280929 & - & Puerto Colera, Girona, Spain \\
\hline
\end{tabular}


Table 1 (continued)

\begin{tabular}{|c|c|c|c|c|c|c|}
\hline Species & $18 \mathrm{~S}$ & $16 \mathrm{~S}$ & $\mathrm{COI}$ & $28 \mathrm{~S}$ & IST2 & Locality \\
\hline Syllis ypsiloides Sg 19 & KX281035 & KX280970 & KX280985 & KX280916 & - & $\begin{array}{l}\text { "Mainif point," between Balayan Bay and } \\
\text { Batangas Bay, Luzon Island, Philippines }\end{array}$ \\
\hline Syllis ypsiloides $\mathrm{Sg} 20$ & KX281032 & KX280971 & KX280989 & KX280913 & - & Easter Island, Chile \\
\hline Syllis variegata & KX281049 & KX280974 & KX281010 & KX280930 & - & $\begin{array}{l}\text { "Polpollcan,” El Nido, Palawan Island, } \\
\text { Philippines }\end{array}$ \\
\hline Trypanedenta gemmipara & - & KX084920 & - & - & - & Cavalli Islands, New Zealand \\
\hline Trypanedenta gigantea & KX084842 & KX084919 & KX084947 & - & - & Elephant Island, Antarctica \\
\hline Trypanobia asterobia & - & MG053190 & MG053197 & - & - & Japan \\
\hline Trypanobia cryptica & KR604717 & KR534503 & KR534503 & OK172164 & - & Lizard Island, Australia \\
\hline Trypanospina martini & MG053194 & MG053191 & MG053200 & - & - & $\begin{array}{l}\text { "Mainif point," between Balayan Bay and } \\
\text { Batangas Bay, Luzon Island, Philippines }\end{array}$ \\
\hline Trypanosyllis aeolis & KX084817 & KX084913 & KX084968 & - & - & El Toro Island, Mallorca, Spain \\
\hline Trypanosyllis californiensis & KX084821 & KX084869 & KX084938 & KX084812 & - & La Jolla, San Diego, California \\
\hline Trypanosyllis cristoboi & KX084818 & KX084914 & KX084935 & - & - & $\begin{array}{l}\text { "Sepok point," between Balayan Bay and } \\
\text { Batangas Bay, Luzon Island, Philippines }\end{array}$ \\
\hline Trypanosyllis depressa & KR364795 & KR364797 & KR364801 & - & - & Lizard Island, Australia \\
\hline Trypanosyllis estebani & MG053195 & MG053193 & MG053199 & - & - & Banyuls-sur-mer, France \\
\hline Trypanosyllis kalkin & - & KX084880 & KX084970 & - & - & Las Cruces, Valparaíso Region, Chile \\
\hline Trypanosyllis cf. krohnii Tk6 & KX084831 & KX084878 & KX084952 & - & - & Port Jackson, NSW, Australia \\
\hline Trypanosyllis cf. krohnii Tk12 & KX084823 & KX084881 & KX084940 & KX084814 & - & Itapua Beach, Bahgo, Brazil \\
\hline Trypanosyllis cf. krohnii Tk41 & KX084833 & KX084884 & KX084957 & - & - & $\begin{array}{l}\text { "Beatrice Point," Sombrero Island, Bal- } \\
\text { ayan Bay, Luzon Island, Philippines }\end{array}$ \\
\hline Trypanosyllis cf. krohnii Tk38 & - & - & KX084941 & KX084815 & - & $\begin{array}{l}\text { Maunalaya Bay Beach Park, South Shore } \\
\text { of Oahu, Hawaii }\end{array}$ \\
\hline Trypanosyllis krohnii & - & EF123817 & EF123786 & - & - & Banyuls sur Mer, France \\
\hline Trypanosyllis leivai_1 & - & KX084874 & KX084942 & KX084816 & - & Philippines \\
\hline Trypanosyllis leivai_2 & KX084827 & KX084876 & KX084953 & - & - & $\begin{array}{l}\text { "Beatrice Point," Sombrero Island, Bal- } \\
\text { ayan Bay, Luzon Island, Philippines }\end{array}$ \\
\hline Trypanosyllis luquei & - & - & KX084991 & - & - & Anza Cove,SanDiego, California \\
\hline $\begin{array}{l}\text { Trypanosyllis luzonensis } \\
\text { Tluzo19 }\end{array}$ & KX084840 & KX084908 & KX084964 & - & - & $\begin{array}{l}\text { "Sepok point," between Balayan Bay and } \\
\text { Batangas Bay, Luzon Is, Philippines }\end{array}$ \\
\hline $\begin{array}{l}\text { Trypanosyllis luzonensis } \\
\text { Tluzo1 }\end{array}$ & KX084838 & KX084892 & KX084963 & - & - & $\begin{array}{l}\text { Hong Kong University of Science and } \\
\text { Technology, Hong Kong, China }\end{array}$ \\
\hline Trypanosyllis sanchezi & MG053196 & MG053192 & MG053198 & - & - & El Cachucho MPA, Cantabrian Sea, Spain \\
\hline Trypanosyllis sp. & KX084818 & KX084914 & KX084935 & KX084809 & - & $\begin{array}{l}\text { Sepok Point, Between Balayan Bay and } \\
\text { Batangas Bay, Luzon Is, Philippines }\end{array}$ \\
\hline Trypanosyllis taboadai & KX084819 & KX084866 & KX084936 & KX084810 & - & Cavalli Islands, New Zealand \\
\hline Typosyllis antoni & MN545360 & NC_031404 & NC_031404 & - & - & Aquarium Leipzig, Germany \\
\hline Typosyllis edensis & JF903658 & JF903732 & JF903789 & - & - & New Port, NSW, Australia \\
\hline Typosyllis gerundensis & KX084847 & KX084861 & KX084929 & - & - & El Toro Island, Mallorca, Spain \\
\hline Xenosyllis moloch & KX084857 & KX084916 & KX084944 & - & - & $\begin{array}{l}\text { Koala point,” Balayan Bay, Luzon Island, } \\
\text { Philippines }\end{array}$ \\
\hline Xenosyllis scabroides & JF913974 & JF903753 & - & - & - & Lizard Island, QLD, Australia \\
\hline
\end{tabular}

obtained with the primers from Folmer et al. (1994) and Simon et al. (1994), respectively. For $18 S, 28 S$, ITS2, and extending $C O I$, new specific primers for Ramisyllis were designed with CLC Genomic Workbench 20 (Online Resource 2). The products of successful amplification were purified using ExoSAP-IT PCR Product Cleanup protocol (ThermoScientific). Sequences were revised with
BioEdit (Hall, 1999) and CodonCodeAligner (CodonCode, Dedham, MA, USA).

Sequences of other species of Syllinae used in the phylogenetic analyses were obtained from GenBank and selected based on the maximum number of available genes ( $\mathrm{COI}$, $16 S, 18 S$, and 28S) (Table 1). The analysis included representatives of the main groups previously identified as 


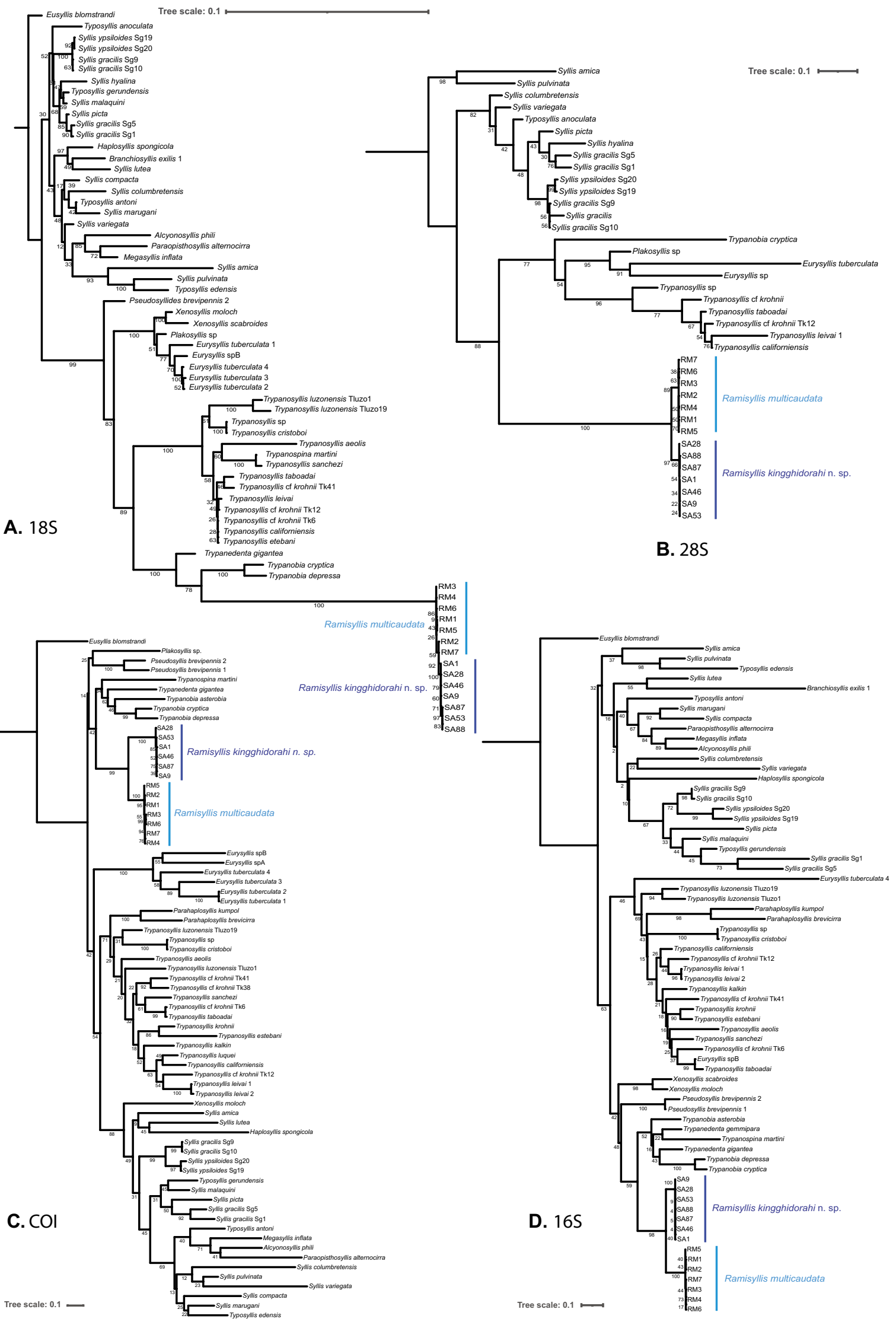


4Fig. 2 Maximum likelihood trees. A Tree obtained when analysing $18 S$ data set. B Tree obtained when analysing $28 S$ data set. C Tree obtained when analysing $C O I$ data set. D Tree obtained when analysing $16 S$ data set. Bootstrap support values below nodes. Syllis and Typosyllis species as they were originally described

closely related to $R$. multicaudata (Aguado et al., 2015a), and the main groups within Syllinae (Aguado et al., 2012; Ribeiro et al., 2020). The Eusyllinae Eusyllis blomstrandi (Malmgren, 1867) was used as the outgroup.

\section{Genome sequencing and analyses}

For Illumina sequencing, double index sequencing libraries with average insert sizes of around $300 \mathrm{bp}$ were prepared (Meyer \& Kircher, 2010). The libraries were sequenced as 125 bp paired-end run, on an Illumina Hi-Seq 2000. Base calling was performed with freeIbis (Renaud et al., 2013), adaptor and primer sequences were removed using leeHom (Renaud et al., 2014), and reads with low complexity and false paired indices were discarded. The quality of all sequences was checked using FastQC v.0.11.5 (RNA data) and v.0.11.9 (DNA data) (http://bioinformatics.babraham.ac. uk/projects/fastqc/). Raw data of all libraries were filtered by removing all reads that included more than 5 bases with a quality score below 15 . De novo genome assemblies were conducted with SPAdes 3.15.2 and IDBA-UD 1.1.046 (Peng et al., 2012; Prjibelski et al., 2020) using an initial k-mer size of 21 , an iteration size of 10 , and a maximum k-mer size of 81 . N50 and average GC-content of genome assemblies were evaluated using QUAST v.5.0.2 (Gurevich et al., 2013). All sequence data were submitted to the Sequence Read Archive of the National Centre for Biotechnology Information (NCBI-SRA) (Table 1).

For transcriptome data, Trimmomatic v.0.38 (Bolger et al., 2014) was used after sequencing to trim and filter low quality reads with the options ILLUMINACLIP HEADCROP:10 LEADING:20 SLIDINGWINDOW:5:20 MINLEN:70. The surviving trimmed reads were used for de novo transcriptome assembly of $R$. multicaudata using Trinity 2.4.0 (Grabherr et al., 2011; Haas et al., 2013).

In the obtained genome assembly of the Japanese Ramisyllis SA1, the $18 S$ and $28 S$ gene sequences were identified using BLASTN (Altschul et al., 1990; Zhang et al., 2000) searches with the sequences of $18 S$ from $R$. multicaudata (KR04716) and 28S of Typosyllis anoculata (HartmannSchröder, 1962) (DQ790071) as query. COI and $16 \mathrm{~S}$ gene sequences were obtained from the assembled mitochondrial genome (see below). COI, $16 S$, and $18 S$ sequences of $R$. multicaudata (KR534502, KR04716) from Aguado et al. (2015a) were used to identify these gene sequences in the new transcriptome of the Darwin R. multicaudata RM7. The $28 S$ gene sequence found in the assembly of the Japanese specimen was used as query to search for homologous sequences in the assembled transcriptome of $R$. multicaudata, as well as in the previously available assemblies of $T$. cryptica and $R$. multicaudata (Aguado et al., 2015a).

The ITS 2 marker was identified in the obtained genome and transcriptome using the available cluster ITS15.8S-ITS2-28S from Proceraea cornuta (Agassiz, 1862) (AF212165) and used to estimate genetic distances.

\section{Mitochondrial genome annotation and analyses}

The complete mitochondrial genome (mt-genome) of the Japanese holotype SA1 (Table 1) was identified using BLASTN searches with the mt-genome of $R$. multicaudata (KR534502) (Aguado et al., 2015a) as query. Mt-genome annotation and prediction of secondary structure of tRNAs and rRNAs were performed using MITOS webserver (Bernt et al., 2012) with the invertebrate mitochondrial code (NCBI code) (Online Resource 3). All automatic annotations were edited manually. Circular mt-genome representation was obtained with GenomeVx (Conant \& Wolfe, 2008).

AT and GC skew were determined for the complete mitochondrial genomes (plus strand) according to the formula AT skew $=(\mathrm{A}-\mathrm{T}) /(\mathrm{A}+\mathrm{T})$ and $\mathrm{GC}$ skew $=(\mathrm{G}-\mathrm{C}) /(\mathrm{G}+\mathrm{C})$, where the letters stand for the absolute number of the corresponding nucleotides in the sequences (Perna \& Kocher, 1995). Characterization of codon usage bias was calculated with DAMBE7.2.152 (Xia, 2018) (Online Resource 4).

\section{Phylogenetic analyses}

Each marker was aligned separately using the MAFFT v7 online tool (Katoh \& Standley, 2013; Katoh et al., 2017) with default parameters and gap open and extension values, and using the iterative refinement method E-INS-i. Alignments were manually checked using Bioedit v7.2 (Hall, 1999) and AliView v1.27 (Larsson, 2014). Ambiguously aligned $18 S$ regions were checked and slightly manually improved based on a $18 S$ alignment performed only with sequences of Ramisyllis. All alignments are available at TreeBASE (https:// www.treebase.org/). Single genes (COI, 16S, 18S, 28S) were concatenated using FASconCAT-G (Kück \& Longo, 2014; Kück \& Meusemann, 2010). Maximum Likelihood (ML) tree inference of each gene was analysed with IQ-TREE v1.6.12 (Chernomor et al., 2016; Nguyen et al., 2015), and best fitting models were selected with the IQ-TREE embedded instance of Modelfinder (Kalyaanamoorthy et al., 2017) (COI: TIM $2+\mathrm{F}+\mathrm{I}+\mathrm{G} 4$; 16S: TIM $2+\mathrm{F}+\mathrm{G} 4$; 18S: $\mathrm{TN}+\mathrm{F}+\mathrm{I}+\mathrm{G} 4 ; 28 S: \mathrm{TN}+\mathrm{F}+\mathrm{G} 4)$. Tree inference with the concatenated matrix $(C O I+16 S+18 S+28 S)$ was also performed with IQ-TREE in a similar way. In all analyses, each partition was allowed to have its own set of branch lengths 


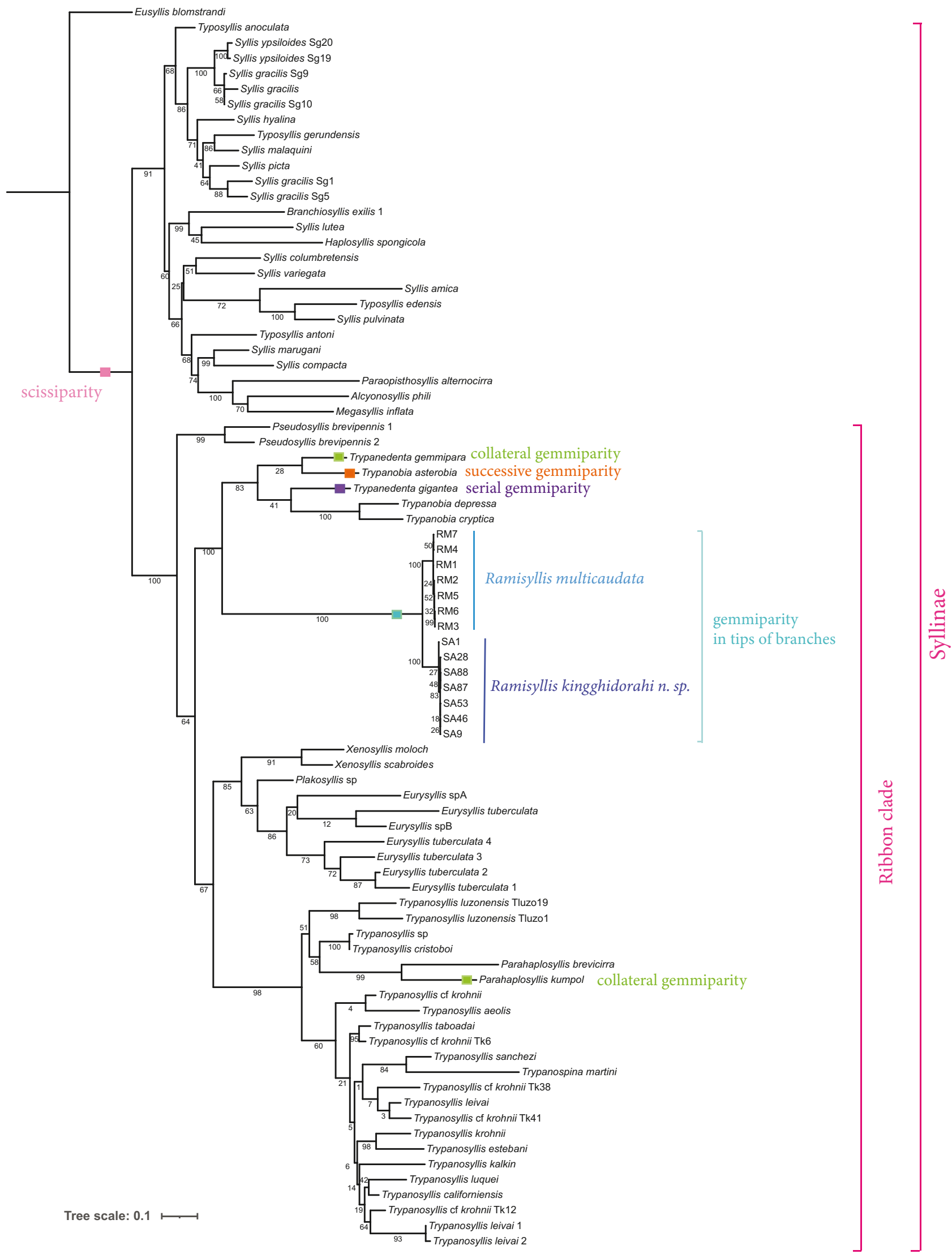

Fig. 3 Maximum likelihood tree obtained when analysing the concatenated data matrix $(28 S+18 S+C O I+16 S)$. Bootstrap support values below nodes. Syllis and Typosyllis species as they were originally described 


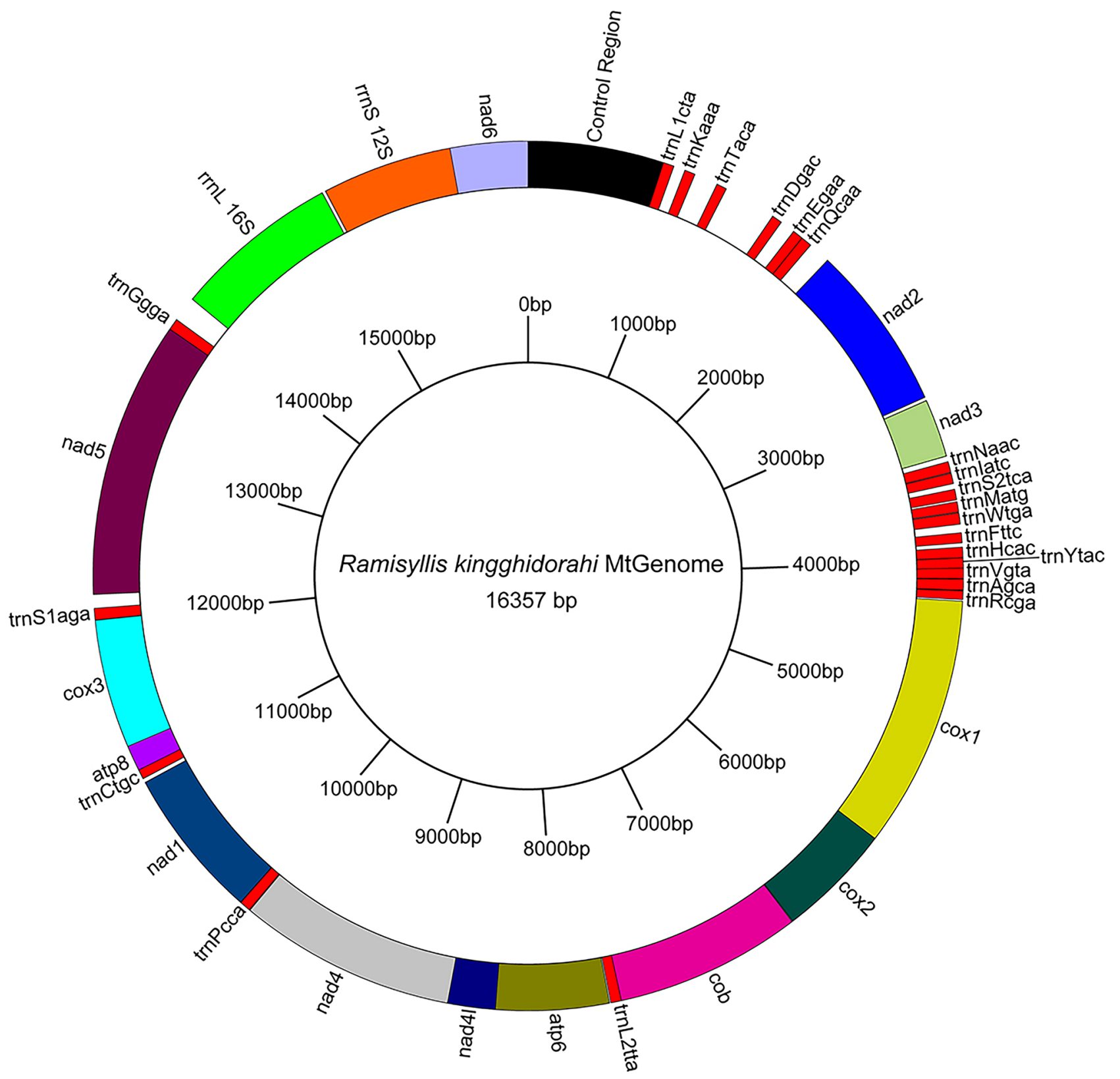

Fig. 4 Circular representation of the mitochondrial genome of Ramisyllis kingghidorahi $\mathrm{n}$. sp

(-sp option). Support values were estimated based on 1000 bootstrap pseudo replicates (B).

\section{Genetic distances and species delimitation}

Genetic distances were only estimated for those species that were phylogenetically closer to Ramisyllis. Terminals with incomplete genes (e.g., only one or two of the three sequencing regions of $18 \mathrm{~S}$ or $28 \mathrm{~S}$, or incomplete $\mathrm{COI}$ and/or $16 \mathrm{~S}$ ) were excluded. Alignments were made with MAFFT v7 and MUSCLE (Madeira et al., 2019). Ambiguously aligned and variable regions in the alignments were recognized and excluded using Gblocks (Castresana, 2000) with relaxed parameters (smaller final blocks, gap positions within the final blocks, and less strict flanking positions allowed). For $16 S$ and $C O I$, within country variability was better assessed using alignments including only sequences of Ramisyllis. For $28 S$ and $18 S$, alignments with only Ramisyllis sequences were considered since the available information for the other terminals only recovered a small portion of $28 S$ and, in the 

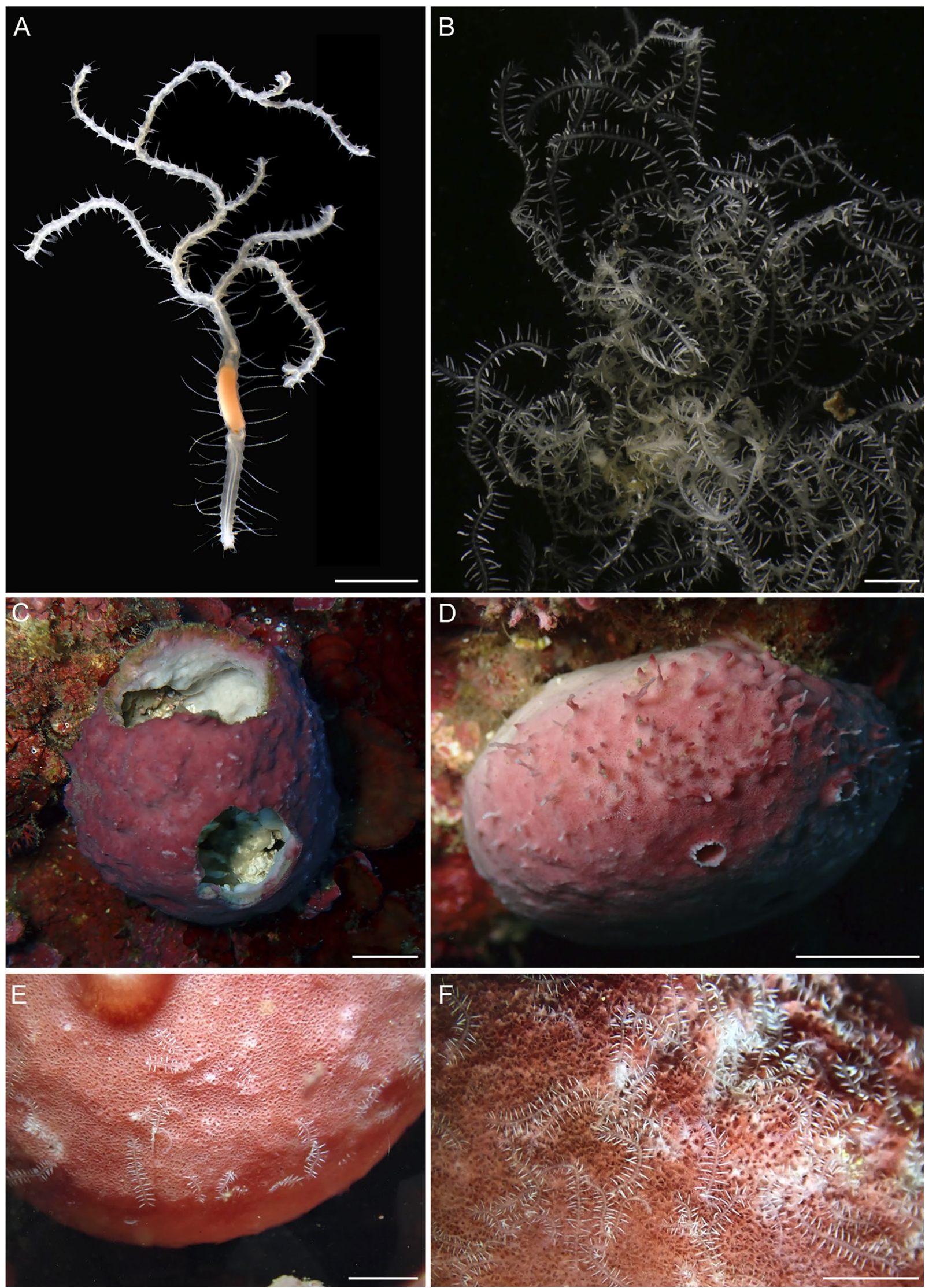
४Fig. 5 Ramisyllis kingghidorahi n. sp. and host sponge Petrosia sp. A Anterior region in dorsal view, prostomium faces down. B Fragment of one specimen. $\mathbf{C}-\mathbf{F}-\mathbf{f}$ Host sponges in their natural habitat. Scale bars: $2 \mathrm{~mm} \mathrm{~A}, \mathbf{B}, 1 \mathrm{~cm} \mathrm{C,} \mathrm{D} \mathrm{and} 5 \mathrm{~mm} \mathrm{E}, \mathbf{F}$

alignment of $18 \mathrm{~S}$ with the rest of the syllines, the regions that remained after excluding ambiguously aligned positions included only the conserved blocks where the variability among Ramisyllis sequences was too low. For ITS2, only sequences of Ramisyllis were analysed since no other ITS2 sequence data is available for Syllinae. Nucleotide divergence over sequence pairs ( $\mathrm{p}$-distance and best fitting substitution model; Online Resources 5-10) was estimated in MEGA v.7 (Kumar et al., 2016).

\section{Results}

\section{Phylogenetic results}

The $18 S$ and $28 S$ sequences of Ramisyllis from Australia and Japan differed considerably from those of all other syllids. $18 S$ showed insertions in regions V2 and V5 (which were especially difficult to align), while for $28 S$ there are still few available sequences. Moreover, only our $28 S$ sequences (both for Ramisyllis and T. cryptica) are complete, while most others available in Genbank represent only a short region (300-500 bp).

All COI, 16S, 18S, and $28 \mathrm{~S}$ trees (Fig. 2), as well as those from the concatenated data matrix $(C O I+16 S+18 S+28 S)$ (Fig. 3) were congruent. In the COI, 16S and 28S ML tree inference analyses, the sequences of Ramisyllis (seven from Australia and seven from Japan) are organized in two wellsupported sister clades (Figs. 2 and 3), with some structure within each clade being detected in $\mathrm{COI}$ and $16 \mathrm{~S}$ (Fig. 2c, d) and no clear within-clade differences for $28 S$ (Fig. 2b). In $16 S, 28 S$, and, especially, COI, the branch length of each clade is long enough to recognize the Australian and Japanese groups (Fig. 2b-d), while in $18 S$, the within-clade branches are extremely short and the Japanese clade is nested within the Australian one, revealing few variations (Fig. 2a). In contrast, the branch length joining Ramisyllis with its sister group Trypanobia-Trypanedenta is considerably long in $18 S$ (Fig. 2a) and $28 S$ (Fig. 2b), whereas it is average when compared to other branch lengths within Syllinae for $16 S$ and $C O I$ (Fig. 2c, d).

The Ramisyllis clade is nested within the "ribbon clade" (sensu Aguado et al., 2015a) in all inferred phylogenies and appears as sister group to Trypanobia and Trypanedenta clade (83B) in the concatenated data analysis (Fig. 3). The "ribbon clade" is always well supported but, in the concatenated data analysis, it shows an early subdivision in a well-supported (99B) small clade (Pseudosyllis brevipennis Grube, 1863 specimens) and a less-supported (64B) large clade including the remaining genera and species. Within this one, a large clade (67B) shows a dichotomy between the Xenosyllis-Plakosyllis-Eurysyllis clade (85B) and Trypanosyllis-Parahaplosyllis (98B). Eurysyllis, Xenosyllis and Parahaplosyllis, all represented by more than one species, are monophyletic, whereas Trypanosyllis appears as paraphyletic.

\section{Mitochondrial genome}

The complete mitochondrial genome of the Japanese Ramisyllis SA1 (Tables 1, S1) was identified in a single contig among the sequences of the assembled lowcoverage genome. It is $16.517 \mathrm{bp}$ long (longer than in $R$. multicaudata) and AT-rich (67\%). A is the most common base (34\%), and $\mathrm{G}$ the least common (12\%). The coding strand has a strong skew of $\mathrm{G} v s . \mathrm{C}(-0.313)$, whereas the AT skew is positive (0.034). The mt-genome contains 37 genes (13 protein-coding genes, two rRNA genes, and 22 tRNA genes) as in most other annelids and typically present in bilaterian mt-genomes (Online Resource 3).

Gene arrangement did not differ between the Japanese and Australian Ramisyllis (Aguado et al., 2015a) (Fig. 4). The mt-genome of the Japanese Ramisyllis has a 821 bp long putative control region flanked by nad6 and trnL1 and 25 non-coding regions ranging from one to $320 \mathrm{bp}$, with the largest one between trnT and $\operatorname{rrnD}$ (Fig. 14; Online Resource 3). ATG and TAA are the start and stop codons for all 13 protein coding genes (Online Resource 3). There is also a marked codon usage bias (Online Resource 4), with NNGs being the least used, and NNTs and, especially NNAs being the most common. The ribosomal RNAs are 1011 bp long for $16 S(r r n L)$, and $795 \mathrm{bp}$ long for $12 S(\mathrm{rrnS})$. The two genes are only separated by an intergenic spacer of $20 \mathrm{bp}$ (Online Resource 3). As in the Australian Ramisyllis (Aguado et al., 2015a), the DHV stem is missing in $\operatorname{trnC}$ and $\operatorname{trnR}$, while shortened in trnS1. In contrast, while the DHV stem in trnS2 is shortened in R. multicaudata from Australia, it is longer in Ramisyllis from Japan.

\section{Genetic distances}

COI genetic distances between Australian and Japanese Ramisyllis are $20-21 \%$ based on a Tajima-Nei model and 17-18\% based on p-distances (Online Resource 5), while the within-clade divergence is $1 \%$ and that between the Ramisyllis clade and other species of the "ribbon clade" range 


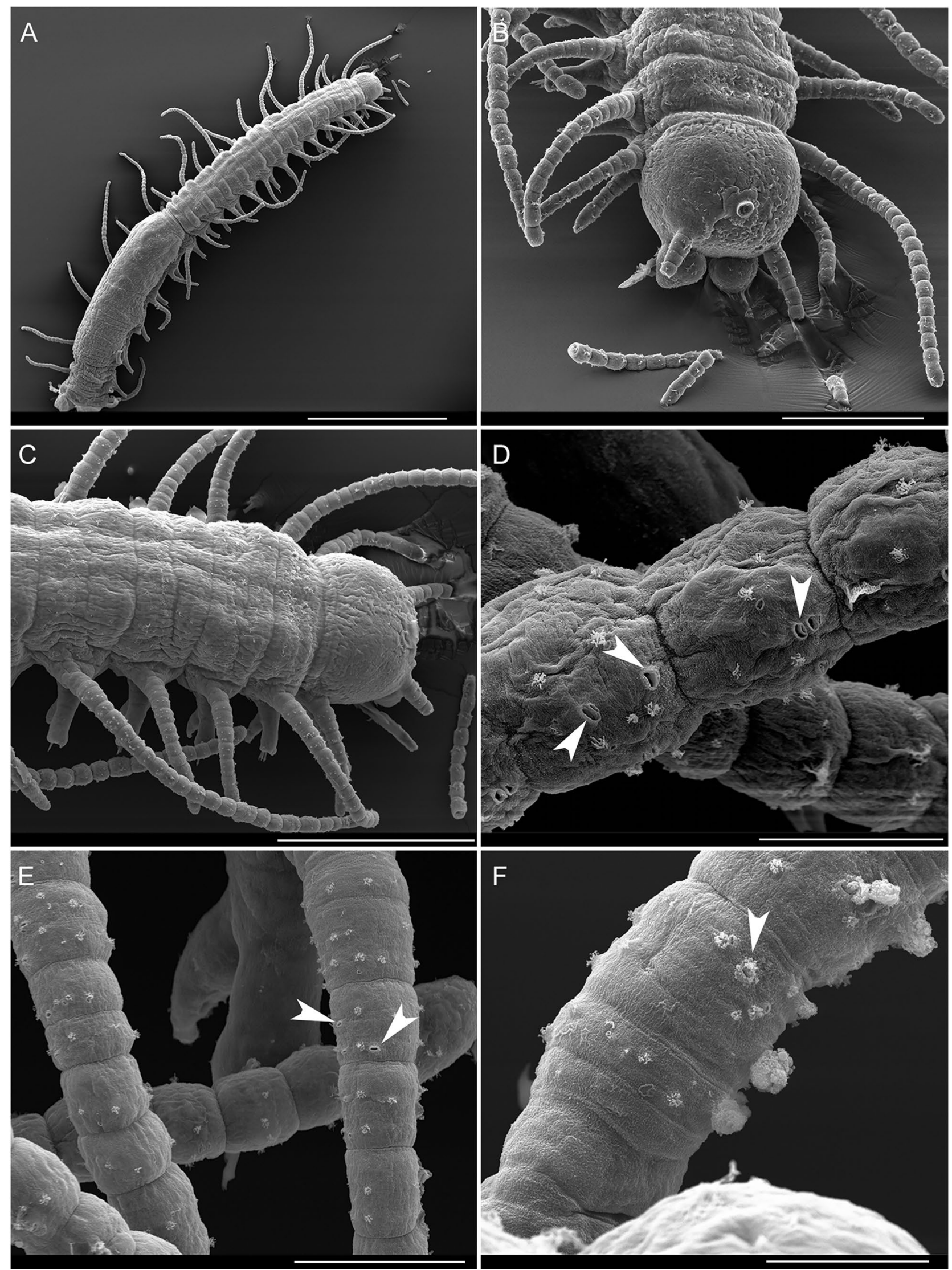


४Fig. 6 Scanning electron microscopy images of Ramisyllis kingghidorahi n. sp. A Anterior region up to first 17 segments, dorsal view. B Prostomium in detail, anterodorsal view (broken antennae on stub). C Prostomium and first segments in detail showing dorsal bands of cilia, dorsal view. D-F Pores on dorsal cirri. Scale bars: $1 \mathrm{~mm} \mathrm{~A}$, $200 \mu \mathrm{m} \mathrm{B}, 300 \mu \mathrm{m} \mathrm{C}, 50 \mu \mathrm{m} \mathbf{E}, 30 \mu \mathrm{m} \mathbf{D}, \mathbf{F}$

between 26 and 40\% (Online Resource 6). Several species of Trypanosyllis show distances of 17-26\% between them (in yellow in Online Resource 6). Trypanedenta gemmipara (Johnson, 1901), Trypanedenta gigantea (McIntosh, 1885), and Trypanobia asterobia (Okada, 1933) show distances of $16 \%$ among them. The $16 S$ genetic distance between the Australian and Japanese Ramisyllis ranges between 10 and $11 \%$ based on Tajima-Nei model (Online Resource 7), while it is $0-1 \%$ within-clades. Distances obtained when analyzing the alignment including only Ramisyllis sequences (not shown) are the same as those obtained in the alignment with the rest of the "ribbon clade" species (Online Resource 7). The distance with other species in the ribbon clade ranges between 25 and $33 \%$ and some species of Trypanosyllis show distances of 11-15\% (in yellow in Online Resource 7). In 28S, the genetic distance between the Australian and Japanese specimens is $4 \%$ (Online Resource 8 ), while in $18 S$, it is $1 \%$ (Online Resource 9), being the latter non-significant. In ITS2, the genetic distance between the Australian and Japanese specimens is $11 \%$ (Online Resource 10).

\section{Taxonomy}

Ramisyllis Glasby et al., 2012

Diagnosis (after Glasby et al. (2012), emendations in bold).

"Ribbon clade" Syllinae, with non-flattened body, more or less cylindrical segments and a multiaxial, dendriform pattern; first branch occurring after segments 14-24. Branches emerging after parapodia (not replacing them or dorsal cirri) and showing same segment size and cirri length as previous branches. Three antennae; palps free to base; two pairs of tentacular cirri; pharynx slender, middorsal tooth absent in adults; dorsal cirri articulated, with alternating thick/slender pattern on mid-body and posterior segments; ventral cirri present, not articulated, inserted proximally; single type of simple chaeta present, tomahawkshaped. Sexes separate. Reproduction by schizogamy, gemmiparitity. Acerous, dimorphic stolons. Commensal inside shallow water species of Petrosia. Mitochondrial gene order strongly modified. Nuclear ribosomal sequences highly derived compared to other Syllinae.

\section{Ramisyllis kingghidorahi n. sp. Aguado, Ponz-Segrelles, Glasby, Ribeiro, Jimi \& Miura. Figures 5-14}

urn:1sid:zoobank.org:act:5E809913-30EF-43A1-831CF6CFED9B40E7.

\section{Diagnosis}

Species of Ramisyllis, sister-group related to R. multicaudata, long anterior tentacular and dorsal cirri (twice long as midbody ones), long proventricle (through 4 segments), stolon stalks similar to other segments in regular branches and proliferation of new branches in intersegmental areas.

\section{Material examined}

HOLOTYPE: Female (ZMUG29,568, MNCNM 16.01/19089-90),

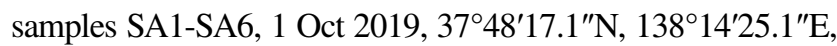
$15 \mathrm{~m}$ deep, coll. Aguado, Ponz-Segrelles, Miura, Oguchi, Omori \& Kohtsuka.

PARATYPES: Paratype 1: male (ZMUG 29,569, MNCNM 16.01/19091-92), samples SA7-22; paratype 2: male (ZMUG 29,571), samples SA28-34; paratype 3: non reproductive specimen (ZMUG 29,573, MNCNM 16.01/19093), samples SA43, 46; paratype 4: male (ZMUG 29,576), samples SA61-62; paratype 5: non reproductive specimen (ZMUG 29,576), sample SA63; paratype 6: male (ZMUG 29,583, MNCNM 16.01/19094-96), sample SA85-91; paratype 7: non reproductive specimen (ZMUG 29,585), sample 96; paratype 8: male (ZMUG 29,586), sample SA102; paratype 9: female (NSMT Pol-P-843), sample 220. All paratypes collected on 1st Oct $2019,37^{\circ} 48^{\prime} 17.1^{\prime \prime} \mathrm{N}$, $138^{\circ} 14^{\prime} 25.1^{\prime \prime E}, 15 \mathrm{~m}$ deep, by Aguado, Ponz-Segrelles, Miura, Oguchi, Omori \& Kohtsuka.

Additional material: 1 female (ZMUG 29,570), 1 male (ZMUG 29,572), 1 female (ZMUG 29,574), 1 male (ZMUG 29,578), 1 non reproductive specimen (ZMUG 29,579), 1 male (ZMUG 29,578), 1 female (ZMUG 29,582), 1 male (ZMUG 29,584), 1 male (ZMUG 29,589), 6 specs. (Sex not determined, undissected sponges with worms inside) (ZMUG 29,587, 29,590-94), male stolons (ZMUG 29,595, 29,598), female stolons (ZMUG 29,597). All specimens collected on 1 st Oct $2019,37^{\circ} 48^{\prime} 17.1^{\prime \prime} \mathrm{N}, 138^{\circ} 14^{\prime} 25.1^{\prime \prime} \mathrm{E}, 15 \mathrm{~m}$ deep, by Aguado, Ponz-Segrelles, Miura, Oguchi, Omori \& Kohtsuka.

\section{Comparative material}

Ramisyllis multicaudata. Seven specimens (RM 1-7, Online Resource 2), Darwin Harbour, Channel Island (type locality), $12^{\circ} 33.2^{\prime} \mathrm{S}, 130^{\circ} 52.4 \mathrm{E}^{\prime}$, coll. and identified by Glasby, Aguado \& Ponz-Segrelles.

Syllis ramosa. 1 specimen University Museum of the University of Tokyo (UMUTZ-Ann-Pc-95) Found in the "gastral cavity and adjacent parts" of Crateromorpha meyeri rugosa in Sagami Bay (around $180 \mathrm{~m}$ deep). Coll. by K. Aoki and identified by A. Izuka (1912).

Syllis cf. ramosa. 1 specimen from the National Museum of Nature and Science of Tokyo (NSMT-Pol 


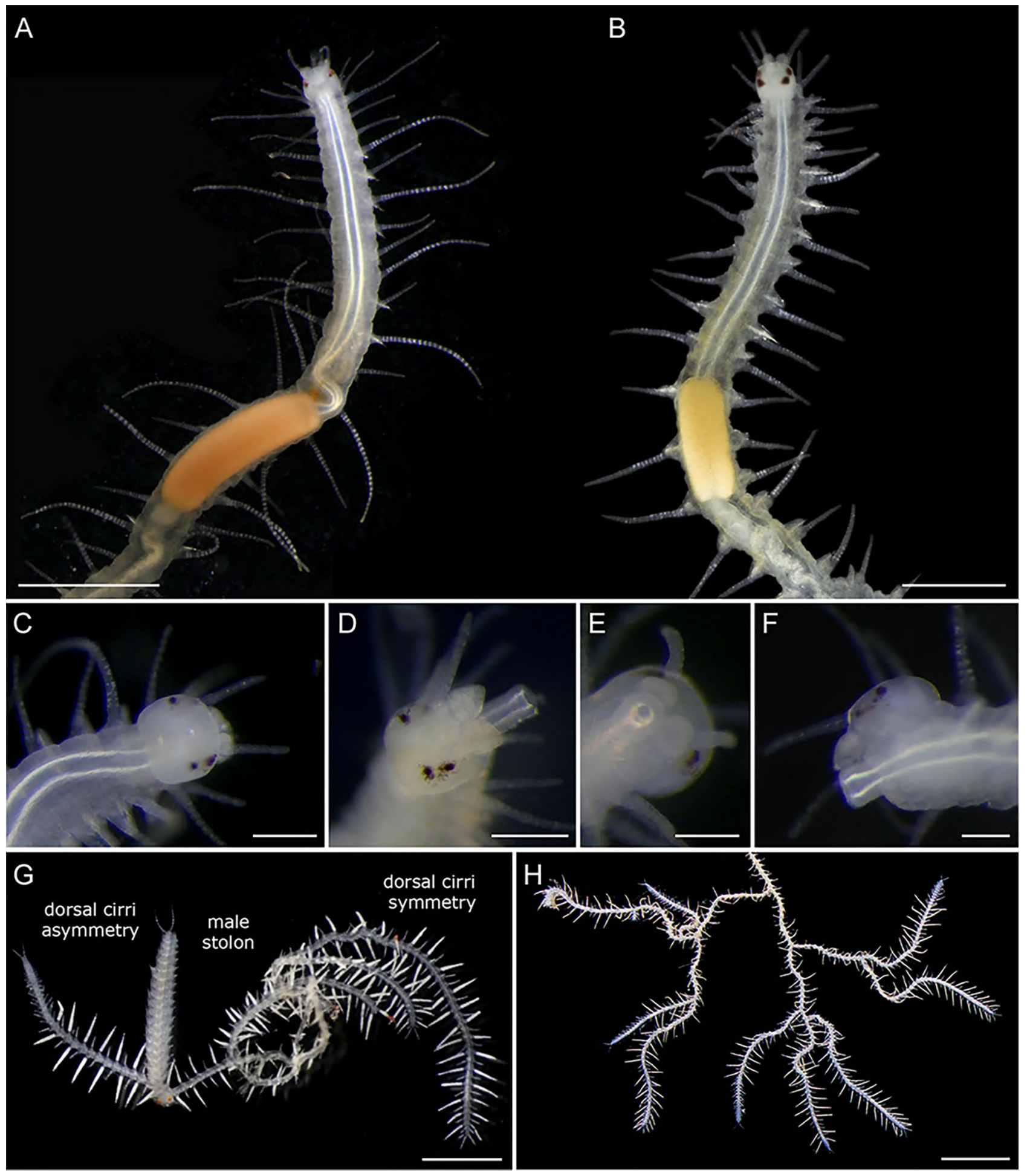

Fig. 7 Stereomicroscopy images of living specimens of Ramisyllis kingghidorahi $\mathrm{n}$. sp. (A, C-H) and Ramisyllis multicaudata $(\mathbf{B})$ for comparison. A Ramisyllis kingghidorahi n. sp. Holotype. B R. multicaudata anterior region, dorsal view; picture modified from PonzSegrelles et al. (2021), with permission. C Prostomium and first segments in detail, dorsal view. D Anterolateral view of prostomium with details of palps and pharynx everted. $\mathbf{E}$ and $\mathbf{F}$. Pharynx everted in ventral view. $\mathbf{G}$ Branching asymmetries in dorsal cirri. $\mathbf{H}$ Branching asymmetries in body shape. Scale bars: $1 \mathrm{~mm} \mathrm{~A}, \mathbf{B}, 200 \mu \mathrm{m} \mathrm{C,} \mathrm{D,}$ $100 \mu \mathrm{m} \mathbf{E}, \mathbf{F}, 2 \mathrm{~mm} \mathbf{G}, \mathbf{H}$ 
S. 1568). Found in "a sponge" at Sagami Bay (around 35-50 m deep), collected and identified by M. Imajima in 2005 .

\section{Etymology}

The name refers to King Ghidorah, the three-headed and two-tailed monster enemy of Godzilla. Both characters were created by Tomoyuki Tanaka based on Japanese mythology and folklore. King Ghidorah is a branching fictitious animal that can regenerate its lost ends. King Ghidorah is assumed to be a male and latinized accordingly.

\section{Distribution and habitat}

Coastal waters of Sado Island, Japan, around $15 \mathrm{~m}$ deep; symbiont of Petrosia sp. (pink form).

\section{Ecology}

The sponges were collected on vertical stone walls, slopes, or small caves, usually in less exposed areas where they were often accompanied by other sponges, encrusting algae, and coralline algae. The sponges measured $5-10 \mathrm{~cm}$ in diameter and were usually irregularly round and pink, with mostly smooth surfaces except some areas showing crests, dead and healed areas (Fig. 5c), and some large oscula (Fig. 5d). Immediately after placing the sponges in trays, many very active, fast-swimming male stolons (see description below) left them. After 2-3 h, swimming female stolons (see description below) also left, moving slower than males. Detached stolons, mostly males, shook vigorously (Video S1), as in other syllids (MTA, personal observation). Dissection revealed only one worm specimen per sponge, most of them developing stolons (ten were males, five females), though not all of them showed signs of stolonization (four specimens). In sponges containing sexually mature specimens with attached stolons, some fully developed, detached stolons were also found in the sponge canals. All attached and free stolons from the same sponge specimen were of the same sex.

The anterior worm end, considerably less active than the posterior ends, was always at the inner basal area of the sponge. No pattern was observed in the position or orientation of the branches. The sponges were generally widely occupied, particularly in some areas. Worm branches were quite flexible and elastic, which facilitated fluent movement within the canal system. However, even though some branches could move outside the sponge when needed, worms were not able to abandon the sponge, even when some of their branches were dying. In natural conditions, the posterior ends emerged from the ostia or the oscula only in one specimen. In the laboratory, posterior ends moved on the sponge surface (Fig. 5e, f).

\section{Description}

External morphology Dendriform branching body with one anterior and multiple posterior ends (Fig. 5a, b). Random branching asymmetry (Fig. 7h). Body subcylindrical, ventrally flattened, mostly translucent (except some yellowish or brownish areas in vivo). Holotype $0.36 \mathrm{~mm}$ wide at proventricle level, without parapodia. Branches always dichotomous, emerging at approximately right angles from intersegmental areas (Fig. 9a-d). Paired branches from same segment not seen. Holotype with first branching point after segment 24, second 4 and 6 segments later on each respective branch (Fig. 5a). Number of segments between two contiguous ramifications lacking obvious branching pattern (4-10 segments in holotype anterior branches to 10-20 segments between branching points in other regions). Most midbody segments as long as wide (70 $\mu \mathrm{m}$ length) (Fig. 9a-c, e-f), with some areas with much longer segments, 2-3 times as long as regular ones (174 $\mu \mathrm{m}$; Fig. 9d), rectangular, yellowish or brownish, with much shorter dorsal cirri (Fig. 9d).

Prostomium rounded, with two pairs of eyes, anterior pair larger than posterior one; antennae articulated, median one slightly longer ( 8 articles in holotype) than lateral ones (6-7 articles in holotype) (Figs. 6a-c and 7a, c-d). Median antenna placed behind lateral ones (Fig. 6b). Palps small, conical, ventrally directed (Fig. 6b). Nuchal organs absent (Fig. 6b, c). Tentacular cirri articulated, dorsal ones longer (11 articles in holotype) than ventral ones ( 7 articles in holotype) (Fig. 6b, c). Dorsal surface of segments anterior to proventricle with a transversal band of cilia (Fig. 6c), then with bunches of cilia in proventricular segments (Fig. 10i) and with minute crests on midbody segments in one specimen (Fig. 10e-g).

Dorsal cirri usually straight, stretched horizontally in life (Fig. 7h), articulated, with those in segments anterior to first branching point longer (23 articles in holotype) than remaining ones (11-15 articles in holotype) (Fig. 5a). Anterior dorsal cirri as: 1st long, 2nd short, 3rd short, 4th long, 5th short, 6th long, 7th short, 8th short, and 9th long; remaining dorsal cirri generally with a strong long-short alternation in length (6-11 vs. 3-7 articles) (Fig. 9e, f). Longer dorsal cirri wider than short ones (Fig. 8). Some midbody branches with long yellowish segments (see above) and dorsal cirri with 1-4 articles lacking clear length alternation (Fig. 9d). Dorsal cirri length and shape symmetrical on each segment, but symmetry occasionally lost (one long and one short dorsal cirrus on same segment) (Fig. 7g). Dorsal cirri with spiral glands, larger and more remarkable in long ones (Figs. 8a, c-e, and 


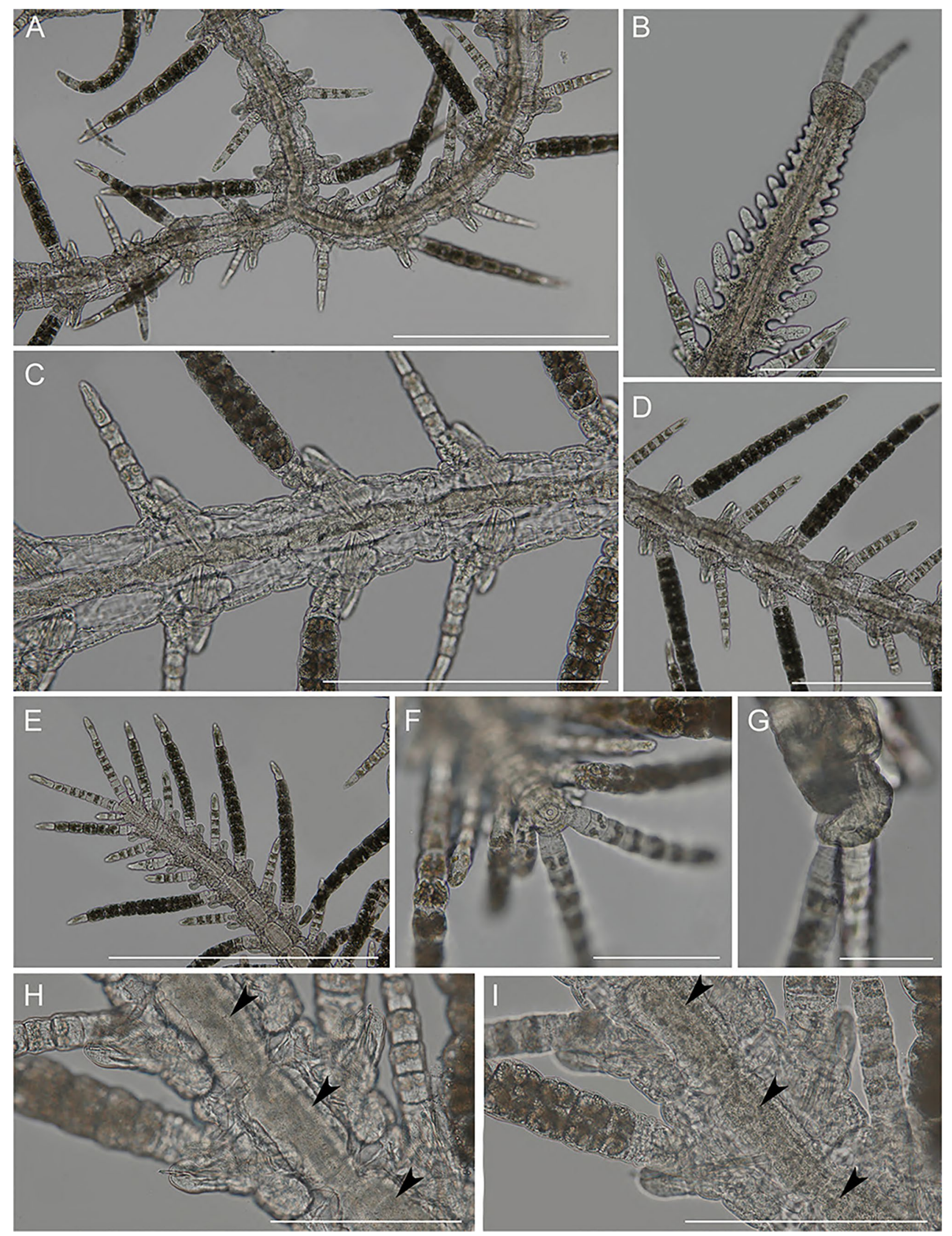


४Fig. 8 Light microscope images of living specimens of Ramisyllis kingghidorahi n. sp. A Branching point. B, E-G Posterior ends showing pygidia. C, D, H, I Midbody segments in regions of long dorsal cirri. Arrows point to the ventral blood vessel in $\mathbf{H}$ and the digestive tract in I.A, D, E, and $\mathbf{I}$ in dorsal view. $\mathbf{B}, \mathbf{C}, \mathbf{F}$ and $\mathbf{H}$ in ventral view. G In lateral view. Scale bars: $500 \mu \mathrm{m} \mathrm{A}, \mathbf{E}, 200 \mu \mathrm{m} \mathrm{B}, \mathbf{C}, \mathbf{D}, 100 \mu \mathrm{m}$ $\mathbf{F}, \mathbf{H}, \mathbf{I}$, and $50 \mu \mathrm{m} \mathrm{G}$

11a, c-f), opening exteriorly through both large and minute pores (joined in perforate plates) (Fig. 6d-f). Glandular content bright white in vivo, especially evident in long dorsal cirri (Fig. 7g), turning into intense red and massively protruding outside through pores when dying (Figs. $6 \mathrm{~g}$ and $11 \mathrm{~b}, \mathrm{f}$ ).

Ventral cirri short, unarticulated, digitiform to oval, basally inserted on parapodia, shorter than parapodial lobes, with numerous pores (Fig. 12g). Neuropodia bearing 2-3 simple chaetae (Fig. 12d-f), occasionally one (Fig. 12h), and one pointed acicula (Fig. 11g). Chaetae tomahawk shaped, bifid distally, prominent subdistal spur and series of denticles between teeth and spur; angle and relative sizes of distal teeth varies slightly along the body (Fig. 12a-f, h).

Pygidial cirri articulated, resembling dorsal cirri of posterior segments (9-10 articles) (Figs. 8e, f, and 10b). Numerous posterior ends regenerating with shorter dorsal and pygidial cirri (Fig. 10a). Anal openings densely ciliated (Fig. 10c, d).

Internal anatomy Alimentary canal visible by transparency (Fig. 8a, c, i). Pharynx slender, through 12 segments in holotype, about one-fourth width of proventricle (Figs. 5a, 7a). Long, slender, cylindrical, strongly-cuticularized, with no tooth or trepan, partially eversible (Figs. 7d-f). Pharynx mostly straight, with a curve anterior to proventricle visible when moving (Fig. 7a). Proventricle prominent, barrelshaped, almost as wide as body width, filling coelomic cavity, extending through $4-5$ segments (15-18 in holotype) (Figs. 5a and 7a). Alimentary canal continuous through all branches. Content visible by transparency as a transparent fluid (Fig. 8a), occasionally with some brownish particles (Fig. 8c). No sponge tissue identified inside. Content of digestive tube moving through peristalsis in vivo, with posterior ends (last 10-20 segments, including anus) internally densely covered by cilia (Video S2) visible by transparency and through anus (Fig. 10c, d). A pair of nephridia per segment at basis of parapodia (Video S3). Each branch with a wide ventral blood vessel visible by transparency (Fig. 8h), ventral to, and wider than digestive tube (Fig. 8i), with a transparent fluid circulating inside and showing peristalsis (Video S4). Incomplete intersegmental anterior and posterior septa delimitate each segment. Digestive tube and ventral blood vessel slightly thinner when going through intersegmental septa (Fig. 8h). Nerve cord ventral, with multiple ramifications (Fig. 13a). Body wall muscles longitudinal, circular ones not seen. External body bifurcation at branching points accompanied by bifurcation of all longitudinal organs (ventral nerve cord, longitudinal muscles, digestive tube, and ventral blood vessel) (Figs. 13a, b), which occupy same relative position in new branches. "Muscular bridge" crossing dorsally over intestine and between ventral nerve cord and ventral blood vessel ventrally to one of three segments coming out from branching point (Fig. 13a, b), being delimitated by three Y-shaped intersegmental septa (Fig. 11h, i; Video S3).

Reproduction and regeneration Sexes separate. Reproduction by gemmiparous schizogamy. Numerous stolons of same sex at end of terminal branches. Attached and detached stolons in a given host sponge are consistently of single sex (either male or female). Stalks undistinguishable from internodes (areas between two branching points) and other terminal branches lacking signs of gametogenesis (Fig. 14i). Segments from stalk with clear alternation in dorsal cirri length (Fig. 14i). No correlation between number of stalk segments and stolon maturity. Ventral regeneration of stalk pygidium starting before stolon detachment (Figs. 13h and 14g, h). Stalks with recently detached stolons showing stubby endings, still ventrally directed, with signs of stolon attachment dorsally, clearly differing from growing tips of new stolons or of developing branches (Figs. 8b, g, and 13f). When dorsal surfaces are repaired, a pair of anal cirri and a new anal opening are developed, followed by regular growth and addition of segments just in front of newly formed pygidium (Fig. 12).

Stolons acerous, with bilobed anterior end, lacking antennae and palps (Figs. 13c, d, and 14a-f). Two pairs of well-developed dorsal (posterior) and ventral (anterior) eyes; ventral pair larger than dorsal one (Fig. 14g, h). A vestigial digestive tube through males and female's stolon segments, bubble like in female first segments, very narrow in remaining segments. Mature female and male stolons having dense bundles of long paddle-like natatory chaetae in addition to typical stock neurochaetae, transparent, long, distally pointed ("wing- or leaf-like") (Fig. 13e), developing in mature stolons, usually seen in recently detached ones. Not seen in still attached, non-fully developed stolons.

Male stolons similar in size to female stolons, but with considerably longer parapodia and narrower bodies (Figs. 13c and 14f), with first two pairs of dorsal cirri longer than following ones (Fig. 14f) and internal oval structures at basis of parapodia (Fig. 13i) (possibly chaetal sacs of the paddle-like chaetae), with first three segments full of yellowish sperm (regionalization) (Fig. 14f). Female stolons with marked positive phototaxis when mature and detached (Video S5), all dorsal cirri of about same length, and segments full of oocytes, even in parapodia (Fig. 14a-e), pink in detached females, white in not completely developed females (Fig. 14c-e). Developing larvae or embryos not observed. 


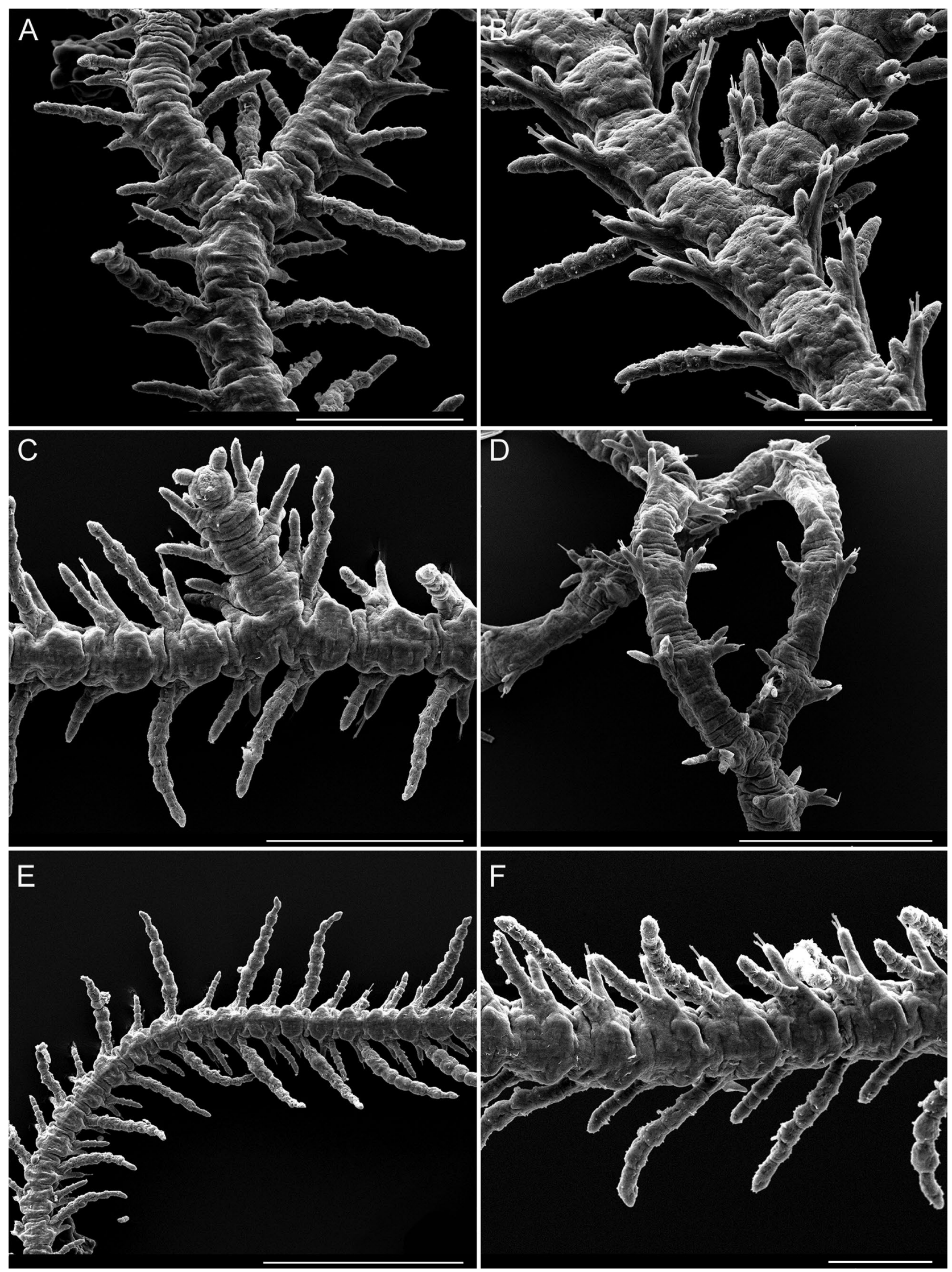


४Fig. 9 Scanning electron microscopy images of branches of Ramisyllis kingghidorahi $\mathrm{n}$. sp. A-F Midbody branching regions with segments of different morphologies, as long as wide with long dorsal cirri in $\mathbf{A}-\mathbf{C}$, much longer with short dorsal cirri in $\mathbf{D}, \mathbf{E}$ and $\mathbf{F}$ Details of cirri alternation in length. A, C, E-F In dorsal view; $\mathbf{B}$ and D in ventral view. Scale bars: $200 \mu \mathrm{m} \mathrm{A}, \mathbf{C}, 100 \mu \mathrm{m} \mathrm{B}, \mathbf{F}, 400 \mu \mathrm{m}$ D, and $500 \mu \mathrm{m} \mathbf{E}$

Remarks Ramisyllis kingghidorahi $\mathrm{n}$. sp. and R. multicaudata (Glasby et al., 2012; Ponz-Segrelles et al., 2021; Schroeder et al., 2017) differ from S. ramosa (except the Red Sea and Imajima's 2005 Sagami Bay specimens) in living from 0 to 20-m depth inside species of Petrosia instead of 100-1000 m depth inside species of Crateromorpha (Izuka, 1912; McIntosh, 1879; Oka, 1895); in having the proliferating area after the parapodia and never replacing it or the dorsal cirri (Glasby et al., 2012) instead of new branches emerging from the parapodium and lacking dorsal cirri as in S. ramosa; in lacking two branches emerging from both sides of the same segment, which may occur in S. ramosa (Pl. XXIII, Fig. 11 in McIntosh,; Fig. 2 in Oka, 1895); in having simple, robust, tomahawk-shaped chaetae instead of slender, hooked at the tip and a fusion line between shaft and blade in S. ramosa (Pl. XVIA; Fig. 1 in McIntosh, 1885); and in newly formed branches acquiring very soon the segment size and cirri length of previous branches instead of showing differences in segments width and smaller and shorter than usual dorsal cirri in S. ramosa (e.g., Fig. 18 in Okada (1937)).

Ramisyllis kingghidorahi $\mathrm{n}$. sp. lives inside an undescribed Petrosia sponge and R. multicaudata in another unidentified species of Petrosia (probably Petrosia cf. nigricans, pers. comm. Dirk Erpenbeck), in both clearly different ecosystems (costal coral reef $v s$. rubble sand with algae, respectively) at different latitudes with different water temperatures. Dorsal cirri are generally longer in $R$. kingghidorahi $\mathrm{n}$. sp. than in $R$. multicaudata, particularly in the anterior end (Fig. 7a, b; Online Resource 11), the proventricle is also longer (4-5 vs. 2-4 segments) (Online Resource 11), stalks are similar to segments in regular branches, while these are narrower with shorter dorsal cirri in $R$. multicaudata (as in S. ramosa) and their stolons also slightly differ in the relative length of some features (e.g., dorsal and ventral cirri, Online Resource 12). In R. kingghidorahi $\mathrm{n}$. sp. the development of a new branch seems to occur just in the intersegmental area, while it was described that in $R$. multicaudata, it begins in front of the posterior septum (Glasby et al., 2012). In R. kingghidorahi n. sp. intersegmental septa of the two pre-existing segments and the newly formed one can be observed by transparency (Fig. 11h, i); they form a "Y" shape (Fig. 11h, i,; Video S3), and appeared to be reduced as in $R$. multicaudata (Ponz-Segrelles et al., 2021), allowing the thinner digestive tube and ventral blood vessel to pass through them (Fig. 8h, i). Nevertheless, in both species, all longitudinal organs bifurcate in the branching points, new branches show internal muscular bridges crossing between the different organs and the ventral blood vessel is considerably enlarged in comparison with other syllids and similar in diameter to the digestive tube (PonzSegrelles et al., 2021).

The three branching syllids show segmental asymmetry (i.e., segments with pairs of dorsal cirri of different length on each side), which intervenes between regions of symmetry (Schroeder et al., 2017) and have been found to show reddish coloration (Glasby et al., 2012; Imajima, 1966; Read, 2001). The glandular material of dorsal cirri in R. multicaudata changes from bright white into red colour when the animals start dying (Ponz-Segrelles et al., 2021), and we observed a similar phenomenon in $R$. kingghidorahi $\mathrm{n}$. $\mathrm{sp}$., with this material protruding through the dorsal cirri pores.

The precise behaviour of female stolons once detached was not determined in $R$. multicaudata, although the presence of paddle chaetae suggested enhanced swimming ability (Ponz-Segrelles et al., 2021; Schroeder et al., 2017). In $R$. kingghidorahi $\mathrm{n}$. sp., female stolons showed a clear positive phototaxis (Video S5) which, together with the paddle-like natatory chaetae, suggests that they leave the sponges for spawning. Syllis ramosa from the Philippines type locality might be viviparous (McIntosh, 1885), but this was neither confirmed for the type material by Glasby et al. (2012), nor for the two species of Ramisyllis.

Previous reports of $S$. ramosa could represent more than one branching species (Glasby et al., 2012), including, for instance, the Red Sea specimen inhabiting a shallow water silicious sponge. Indeed, in agreement with Leslie Harris (pers. comm.), we suggest that a picture by Danièle Heitz of a Petrosia from the Red Sea (Al Birk) with syllid branches emerging from one osculum (https://nomadica.jimdofree. com/vers-marins/annélides/ramisyllis-multicaudata/) likely corresponds to an undescribed species of Ramisyllis. The specimen from Sagami Bay identified by Imajima in 2005 shows differences in chaetal morphology, compared with the three currently known branching species and, thus, might also be an undescribed species. The report of S. ramosa from the southern coast of Jeju Island in South Korea (Lee, 1992) is herein considered as dubious, since it was found on mollusc shells and had compound chaetae.

\section{Discussion}

\section{Ramisyllis kingghidorahi, a new branching species}

All our biological and ecological observations, morphological analyses, internal anatomy observations, and phylogenetic and genetic distance analyses consistently support 

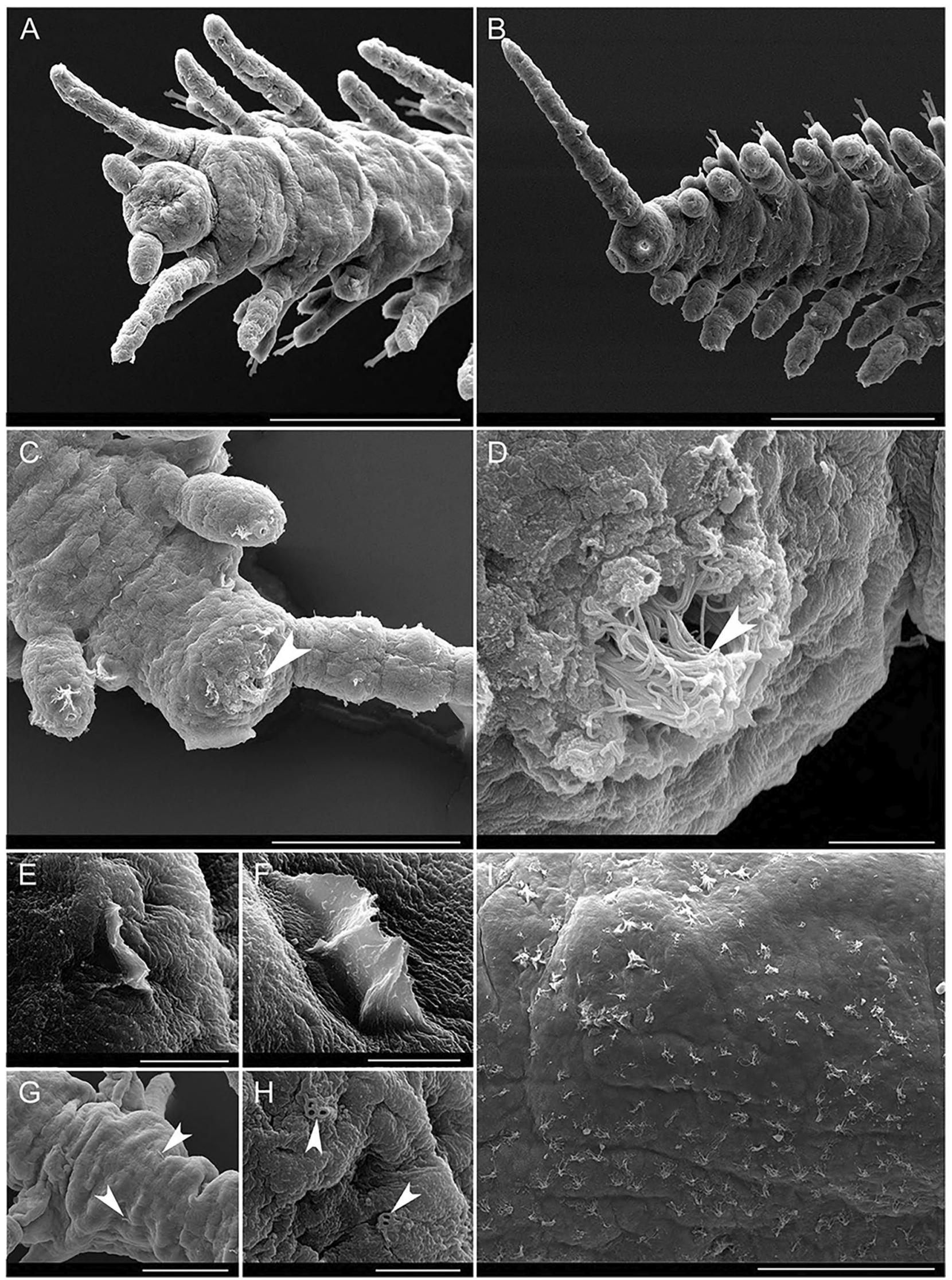
४Fig. 10 Scanning electron microscopy images of Ramisyllis kingghidorahi n. sp., posterior-most regions and epithelium details. A-D Posterior ends. Arrow in $\mathbf{C}$ and $\mathbf{D}$ points to heavily ciliated anus. $\mathbf{E}-$ G Minute crests on the dorsal surface of midbody segments. Arrows point to crests laterally located on the dorsal surface. H Dorsal surface of posterior segments. I Clumps of cilia on dorsal surface of proventricular segments. Arrows pointing to pores in $\mathbf{H}$. Scale bars: $100 \mu \mathrm{m} \mathrm{A}, \mathbf{B}, \mathbf{I}, 50 \mathrm{um} \mathbf{C}, \mathbf{G}, 5 \mu \mathrm{m} \mathbf{D}, \mathbf{E}, 4 \mu \mathrm{m} \mathbf{F}$, and $3 \mu \mathrm{m} \mathbf{H}$

recognition of $R$. kingghidorahi $\mathrm{n}$. sp. as a new species, closely related to $R$. multicaudata. The morphological differences, though clear and consistent among studied specimens, are subtle, and might not be easy to detect by a non-expert eye. This morphological semi-stasis between two clear phylogeographic lineages might be explained by a strict conserved niche (Cerca et al., 2020, 2021) like the Petrosia canal system in which these animals live.

The asymmetrical branching body with unpaired branching may have been inherited from the last common ancestor of both species of Ramisyllis, which was probably already adapted to live inside a sponge canal system. Including $S$. ramosa in a phylogenetic analysis has not been possible. Hence, the reconstruction of ancestral features must consider two possible scenarios: (1) S. ramosa joining $R$. multicaudata and $R$. kingghidorahi in a monophyletic group and (2) $S$. ramosa not being sister to $R$. multicaudata and $R$. kingghidorahi. Under the second scenario, all observed morphological similarities would need to be understood as convergencies resulting from independent adaptations likely related to life in symbiosis with sponges.

Phylogenetic topologies reveal sister group relationships between both species of Ramisyllis, with a clear divergence in $\mathrm{COI}$ and $16 \mathrm{~S}$ (which show faster mutations rates than the nuclear $18 S$ and $28 S$ ). The very high COI distances between both species of Ramisyllis agree with previous studies delimitating species in syllids and annelids in general (Aguado et al., 2019; Álvarez-Campos et al., 2017; Kvist, 2016; Lobo et al., 2016; Nygren et al., 2018), as well as those found for the 16S (Bastrop et al., 1998; Gunton et al., 2020; Miglietta et al., 2010; Radashevsky et al., 2016) and ITS2 markers (Vivien et al., 2015). Conversely, the $28 S$ distance was 1 order of magnitude lower but still significant since this is a slow evolving gene and the obtained distances were similar to those among other syllids (Aguado et al., 2019). In $18 S$ (also a slow evolving gene), distances were lower still. The conserved nuclear gene $18 S$ has previously been used in annelid species delimitation studies as a phylogenetic marker (Cerca et al., 2020, 2021) but is known to usually underestimate the number of species (Tang et al., 2012). Interestingly, Ramisyllis species highly differ from the other syllids in their $18 S$ sequences as revealed by the long branch in the phylogenetic analysis (Fig. 2a) and the clear differences in $18 S$ alignments (Aguado et al., 2015a). This is probably due to expansion regions particularly variable in syllids (Aguado \& Bleidorn, 2010), though its significance is still unknown. The $28 S$ branch is also quite long, although the comparison in this case is less meaningful due to the lower number and quality of the available sequences of Syllinae.

The mt-genome of $R$. kingghidorahi $\mathrm{n}$. sp. resembles that of $R$. multicaudata in gene order, AT and GC skews, codon usage bias, and secondary structure of most tRNAs (Aguado et al., 2015a). However, it strongly differs from most available syllid mt-genomes (Aguado et al., 2016, 2015a), particularly in having a strongly modified gene order and highly derived nuclear ribosomal sequences.

\section{The evolutionary meaning of a branching body}

Many annelids (including syllids) grow by adding segments in front of the pygidium from a segment addition zone (SAZ) (Balavoine, 2014; Bely, 2006; Zattara \& Weisblat, 2020). In Ramisyllis, this occurs simultaneously at the multiple SAZs before each pygidium, more than 500 in $R$. multicaudata (Glasby et al., 2012). The branching ability is related to the presence of multiple SAZs and, thus, it allows these animals to reach a huge size compared with other syllids (usually measuring some $\mathrm{mm}$ to few $\mathrm{cm}$ ). $R$. multicaudata may reach $30 \mathrm{~m}$ long by considering all branches linearly placed one after another (GPS \& MTA, pers. obs.).

The "muscular bridges" at the branching points found in R. multicaudata (Ponz-Segrelles et al., 2021) also occur in $R$. kingghidorahi (Fig. 13a, b). This feature reveals that the bifurcation process does not occur in the SAZ in front of the pygidium, but laterally from fully-developed, mid-body segments. Consequently, the genetic growth-controlling mechanisms usually expressed in the posterior end (Ponz-Segrelles et al., 2018) have to be active in mid-body segments or, alternatively these species may have developed new growthcontrol mechanisms.

The concatenated topology (Fig. 3) shows the Ramisyllis clade as sister to a group comprising Trypanobia and Trypanedenta, as in Aguado and et al. (2015a), with Trypanedenta gemmipara, Trypanedenta gigantea, and Trypanobia depressa (Augener, 1913) reproducing by gemmiparity. Trypanedenta gigantea shows serial gemmiparity (sensu Aguado et al., 2015a), thus producing stolon chains (Álvarez-Campos et al., 2018). Trypanedenta gemmipara shows collateral gemmiparity (sensu Aguado et al., 2015a), thus producing a bunch of stolons attached to a proliferating area in front of the pygidium (Johnson, 1902). Trypanedenta asterobia shows successive gemmiparity (sensu Aguado et al., 2015a), thus developing stolons in various consecutive posterior segments. This is particularly interesting since stolons are formed not only near the pygidium SAZ, but also in several posterior segments (Okada, 1933, 1937), which may imply a simultaneous activation of genetic machinery 

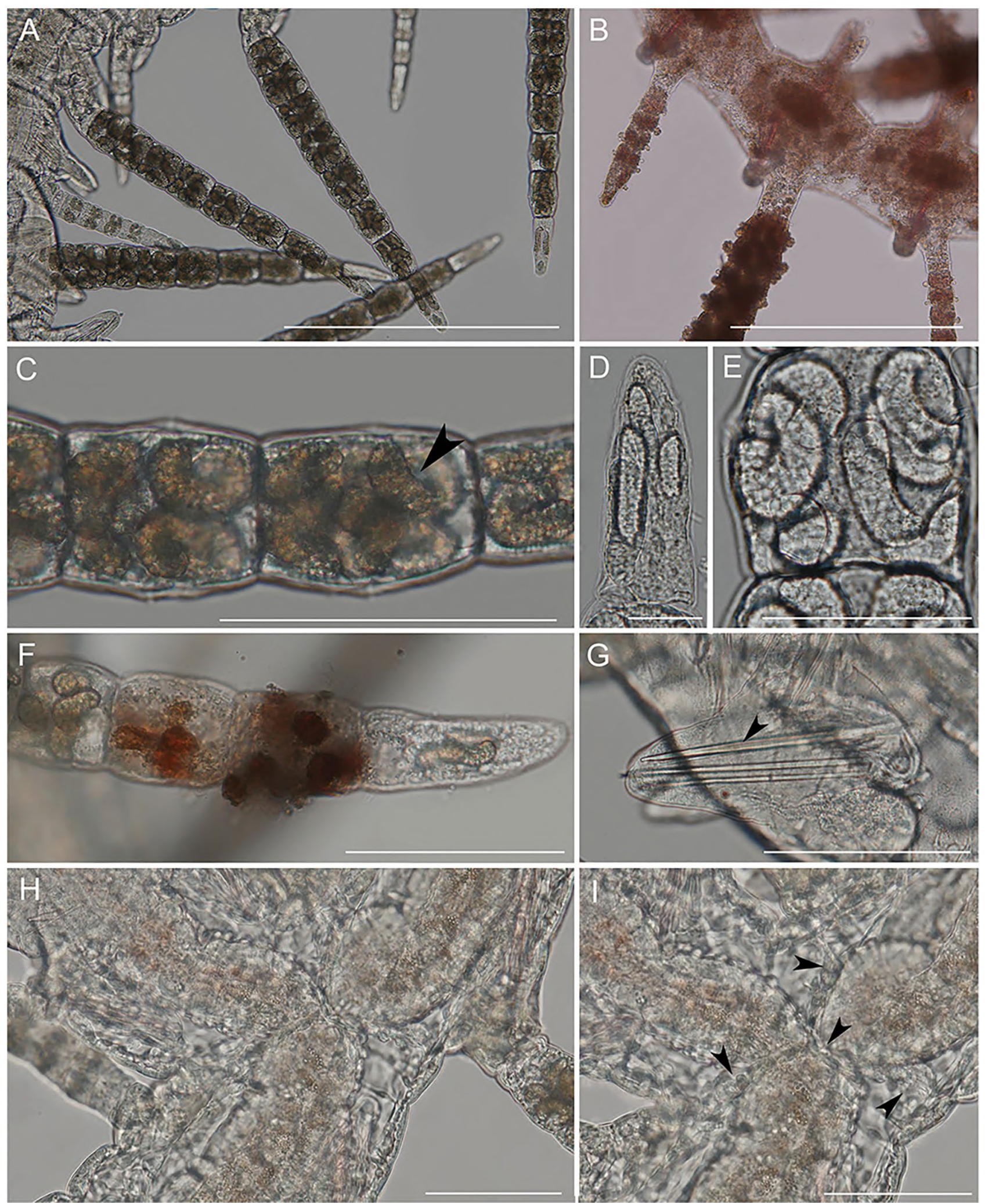

Fig. 11 Light microscope images of living specimens of Ramisyllis kingghidorahi $\mathrm{n}$. sp., dorsal cirri, parapodium and segmental septa. A-F Dorsal cirri and spiral glands; arrow points to spiral gland in $\mathbf{C}$.
G Midbody parapodium, arrow points to pointed acicula, lateral view. H-I Three intersegmental septa forming a "Y shape," dorsal view. Scale bars: $200 \mu \mathrm{m} \mathrm{A}, \mathbf{B}, 50 \mu \mathrm{m} \mathbf{C}, \mathbf{F}, \mathbf{G}, \mathbf{H}, \mathbf{I}, 20 \mu \mathrm{m}$ E, and $10 \mu \mathrm{m}$ D 


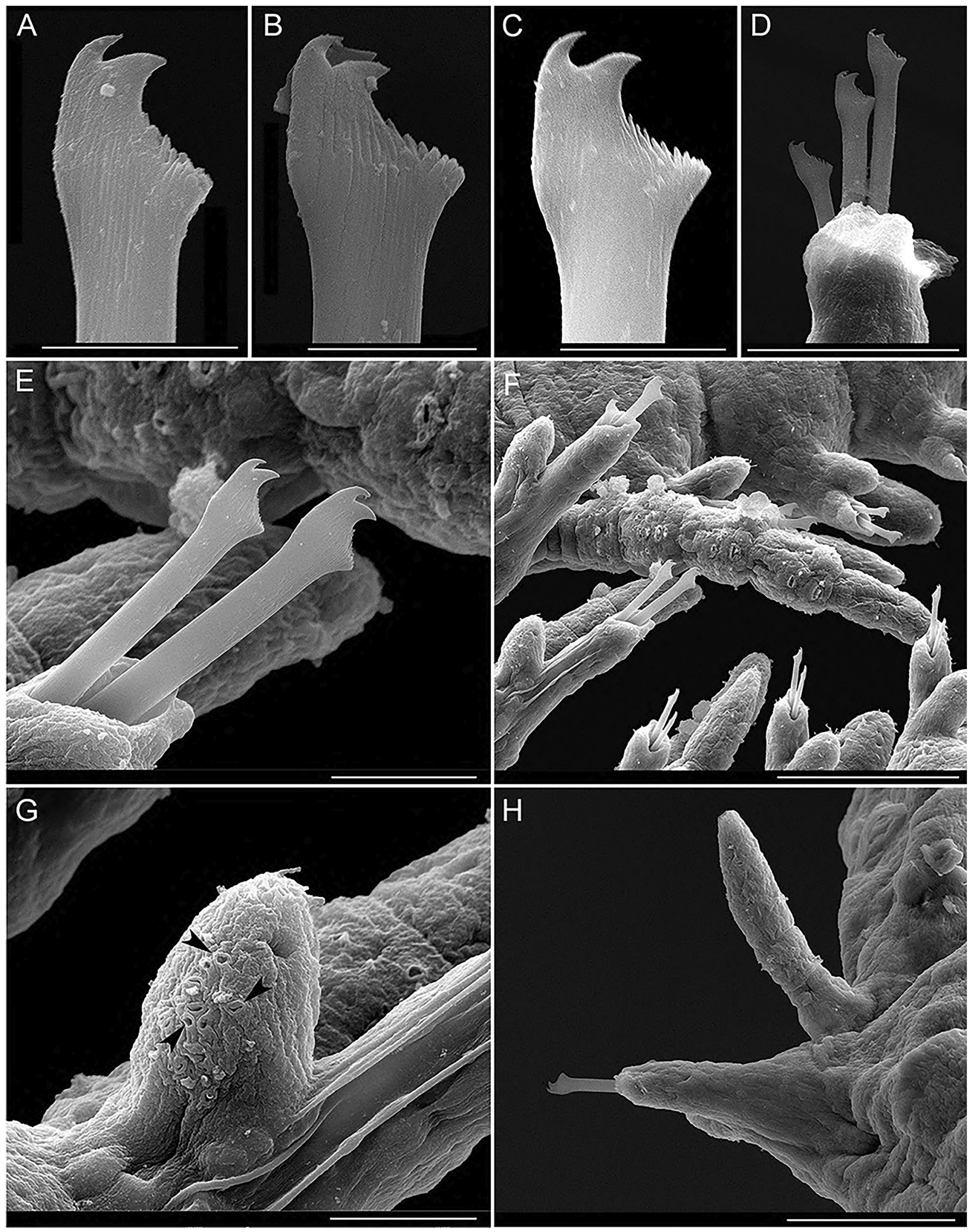

Fig. 12 Scanning microscopy images of Ramisyllis kingghidorahi n. sp, parapodium and chaetae details. A-F, H Midbody tomahawk shaped chaetae. G Ventral cirri, arrows point to pores. Scale bars: $5 \mu \mathrm{m} \mathrm{A}, \mathbf{C} 4 \mu \mathrm{m} \mathrm{B}, 20 \mu \mathrm{m} \mathrm{D}, 10 \mu \mathrm{m} \mathrm{E}$, G, and $50 \mu \mathrm{m} \mathbf{F}, \mathbf{H}$ 

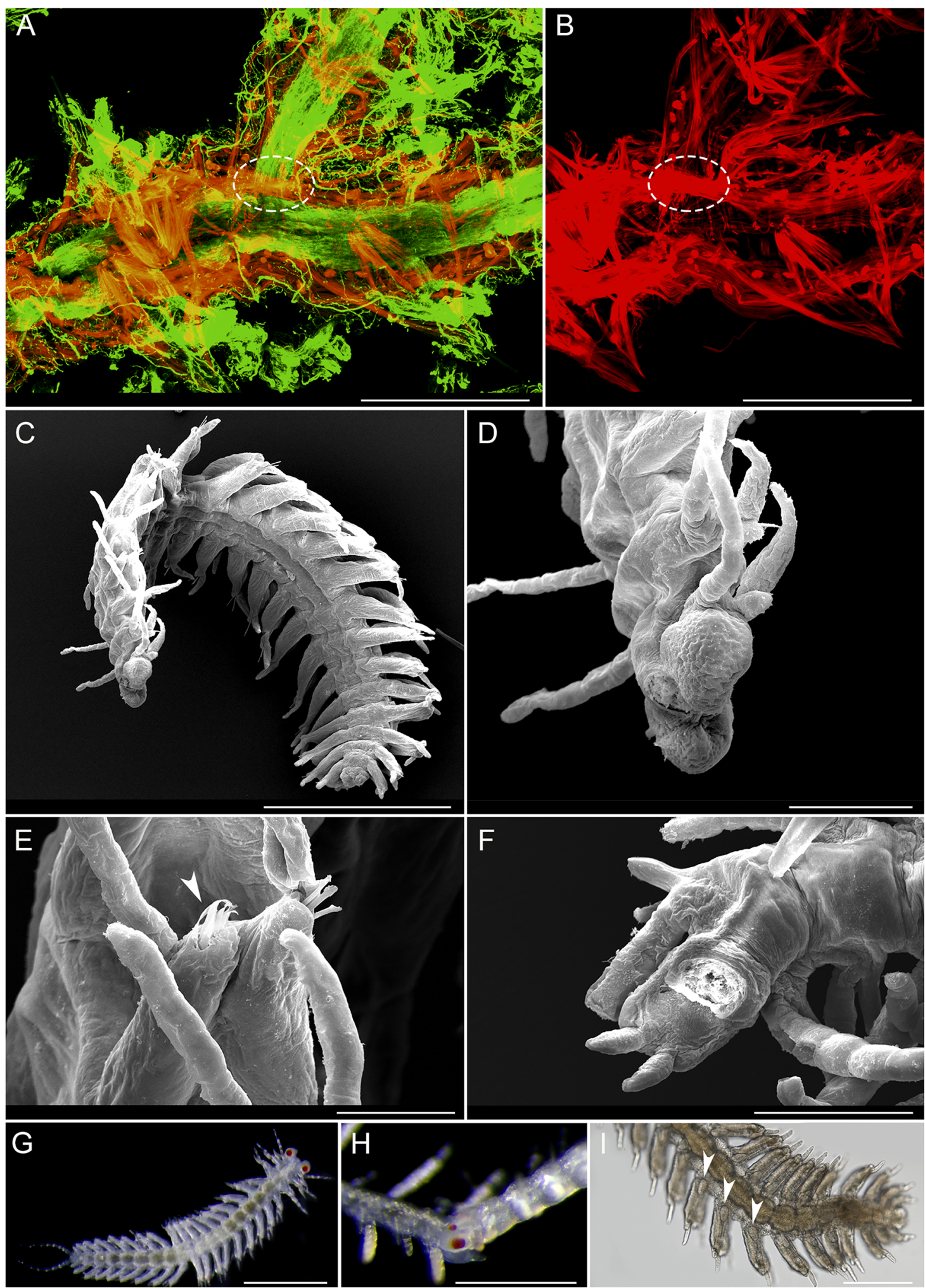

Fig. 13 Internal anatomical details of a branch and scanning microscopy images of stolons. A, B cLSM images of musculature and nervous system immunohistochemical stainings at a branching point, dashed-lined circles mark muscle bridges. C Male stolon. D Head of a male stolon. E Stolon parapodium, arrow points to paddle-like mod- ified chaetae. F Regenerating pygidium, after detachment of stolon. G Male stolon detached. H Stolon attached to the stalk segments. I Posterior segments of male stolon, ventral view, arrows point to oval structures, at the base of parapodia. Scale bars: $250 \mu \mathrm{m} \mathrm{A}, \mathbf{B}, \mathbf{H}, \mathbf{I}$, $500 \mu \mathrm{m} \mathrm{C}, \mathbf{G}, 100 \mu \mathrm{m} \mathbf{D}, \mathbf{F}$, and $50 \mu \mathrm{m} \mathbf{E}$ 

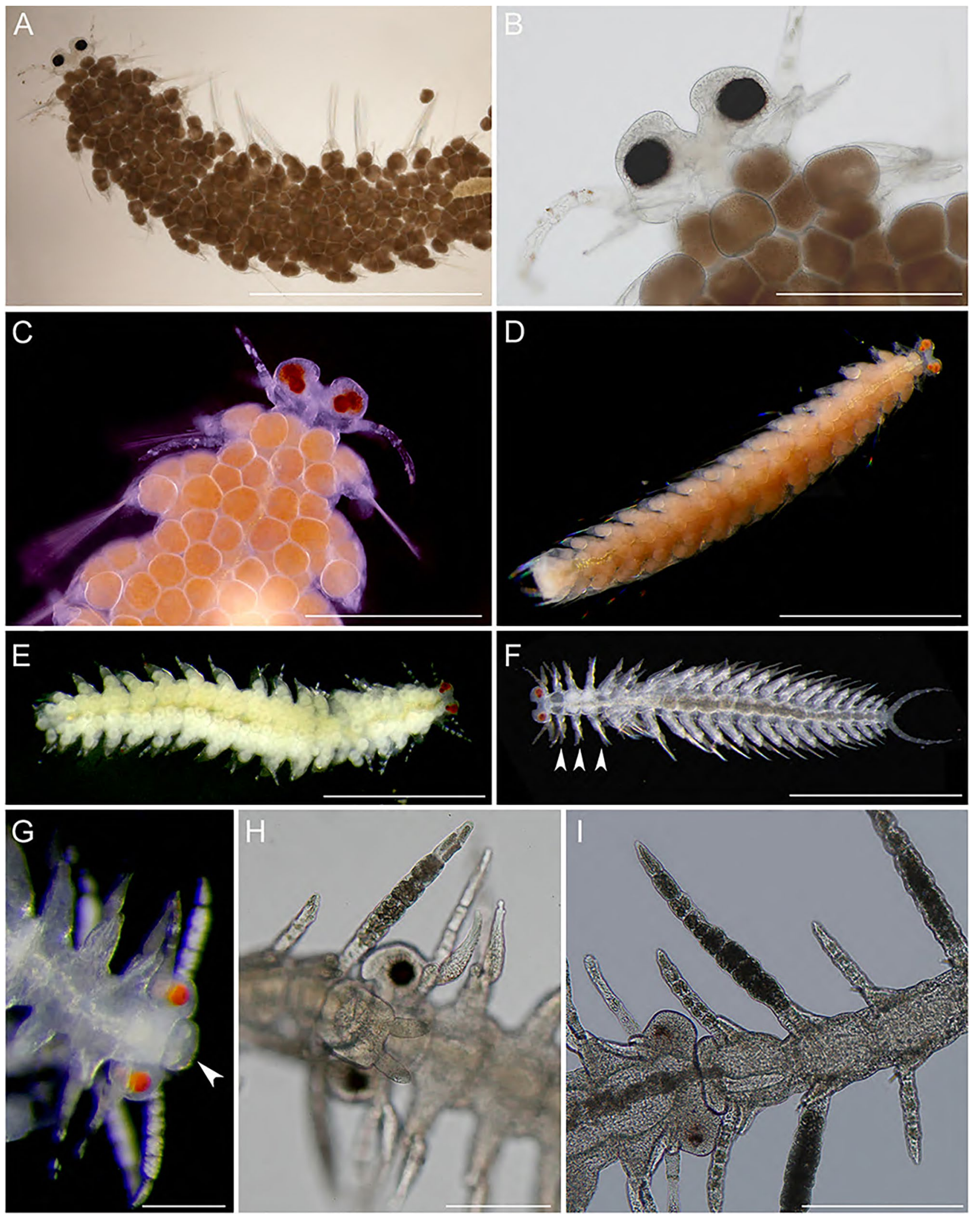

Fig. 14 Sexual dimorphism in stolons. A-E Female stolons, dorsal view. F-I Male stolons; arrows in $\mathbf{F}$ point to the first three segments, the only ones that contain sperm. G-I Stolons attached to the stalk, detail of pygidium in regeneration on the ventral side before detach- ment of the stolon (arrow in $\mathbf{G}$ ), ventral view. $\mathbf{H}$ Light microscope image showing region of stolon head and pygidium regeneration, ventral view. I Stolon attached, dorsal view. Scale bars: $500 \mu \mathrm{m} \mathrm{A,} \mathrm{D,} \mathrm{E,}$ $\mathbf{F}, 100 \mu \mathrm{m} \mathrm{B}, \mathbf{G}, \mathbf{H}$, and $200 \mu \mathrm{m} \mathrm{C,} \mathrm{I}$ 
and regulation processes controlling the development of new tissues in different segments in a way similar to branching syllids (Aguado et al., 2015a). Another species of Trypanobia, $T$. cryptica, was described with only one non fully developed stolon (Aguado et al., 2015b). Thus, it is not clear if it would be able to develop more. Accordingly, the concatenated topology (Fig. 3) reveals the presence of gemmiparity in the common ancestor of Trypanedenta-Trypanobia and Ramisyllis as being the most parsimonious reconstruction. In addition, several Trypanobia species are known to maintain symbiotic relationships with other organisms, such as starfishes and sponges (Aguado et al., 2015b; Okada, 1933), so its hypothetical ancestor might have also been a symbiont.

Symbiotic relationships are frequent in syllids (Martin \& Britayev, 1998, 2018). For instance, species of Haplosyllides Augener, 1922 and Haplosyllis Langerhans, 1879 also live inside sponge canals (Martin et al., 2003, 2009), though they may have developed a different mechanism to infest their sponge hosts. Instead of branching, they have evolved into minute bodies but may reach enormous densities inside the hosts (Martin \& Britayev, 2018), which, to some extent, mimics the branching strategy. Aguado and et al. (2015a) showed that Ramisyllis is not closely related to Haplosyllis, the latter being a member of the large and taxonomically complex Clade B (sensu Ribeiro et al., 2020). However, Haplosyllides has never been included in a previous molecular phylogenetic analysis and a closer relationship with the branched syllids cannot be ruled out. Haplosyllis species have been demonstrated to feed on sponge tissues, likely taking profit of the sponge symbiotic bacteria rather than on the sponge cells (Turon et al., 2019). Aguado and et al. (2015a) did not find any trace of the sponge contamination in the genome data of $R$. multicaudata, which together with no visual evidence of sponge tissue in the digestive tube of Ramisyllis may indicate that branching species do not feed on their host sponges. However, further studies involving more specific techniques, e.g., stable isotope and fatty acids analyses (Taboada et al., 2021) and sponge and worm microbiomes characterization (Turon et al., 2019), would be necessary for more conclusive results. The finding of highly ciliated digestive tubes, especially at the posterior ends and ani, might indicate the use of posterior ends for incorporating fluids into the digestive system. The incorporation of water and food through the posterior end (anus) instead of, or in addition to, the anterior one (mouth) has been reported before in other animals such as holothurians (Jaeckle \& Strathmann, 2013). An uptake of ambient water and certain nutrients through the anus has been also proposed as a possible osmotic balance mechanism for some annelids (Jumars et al., 2015). However, more investigations are needed to confirm this hypothesis.

The acquisition of a complex multiaxial body may be related with an increasing reproductive success, as having multiple posterior ends allows the simultaneous production of numerous stolons at the same time. This ability might sustain the apparently small populations found for $R$. multicaudata and $R$. kingghidorahi $\mathrm{n}$. sp. However, this ability might also be considered a consequence of having a multibranched body. In any case, such a complex body may only be explained by considering the sponge and the worm as a holobiont (Turon et al., 2019). The ramified bodies of the branching syllids might mirror the intricated labyrinth of the sponge canal system in which they live, the sponge canal system, with the ability to produce new fully-developed segments allowing the worm to explore the canals. As such, this can be understood as an example of a change of habitat (from free-living in soft or hard bottoms to inhabiting sponge canals) allowing for the emergence of an evolutionary novelty (branching body) by modification of existing developmental biases which prevented or limited variation (Holló \& Novák, 2012) and, consequently, setting the stage for the evolution of a symbiotic relationship.

Supplementary Information The online version contains supplementary material available at https://doi.org/10.1007/s13127-021-00538-4.

Acknowledgements We would like to acknowledge Mitsuo Honma (Diving Service F.WAVE) for his help during the sampling by SCUBA at Shukunegi and to Felix Thalen and Katharina Henze (Georg August University, Göttingen) for their work in the lab and help with the assembly of genomic and transcriptomic data. We also thank TaeSeo Park for his help with translation of Korean literature. We are grateful to Christoph Bleidorn for his support and opinion about the information covered in this article and two anonymous referees who improved the final version of the manuscript.

Author contributions Conceptualization: MTA, CG, TM; Sampling: MTA, GPS, MK, KO, AO, HK, YI, NJ, TM; Investigation: MTA, GPS, CG, RPR, MK, TM; Resources: MTA, AO, TM; Funding: MTA, TM; Visualization: MTA, GPS, RPR, MK, CF; Supervision: MTA; WritingOriginal draft preparation: MTA; Writing-Review and editing: MTA, GPS, CG, RPR, MK, KO, AO, HK, CF, YI, NJ, TM.

Funding Open Access funding enabled and organized by Projekt DEAL. This study was financed by the Biodiversitätsmuseum (PI:MTA), Georg August University, Göttingen, and by Grant-in Aid for Scientific Research A (No. 18H04006) (PI:TM) from the Ministry of Education, Culture, Sports, Science and Technology of Japan. GP-S was supported by the "Contratos Predoctorales para la Formación de Doctores 2016" program of MINECO, Spain (code: BES-2016076419), co-financed by the European Social Found. RPR was supported by the program "Contratos predoctorales para Formación de Personal Investigador, FPI-UAM,” Universidad Autónoma de Madrid.

Data availability DNA sequences generated in this study are deposited in GenBank under the accession numbers listed in Table 1. Alignments and trees are deposited in TreeBASE: https://www.treebase.org/

Code availability Not applicable.

\section{Declarations}

Ethical approval Not applicable. 
Consent to participate Not applicable.

Consent for publication Not applicable.

Conflict of interest The authors declare no competing interests.

Open Access This article is licensed under a Creative Commons Attribution 4.0 International License, which permits use, sharing, adaptation, distribution and reproduction in any medium or format, as long as you give appropriate credit to the original author(s) and the source, provide a link to the Creative Commons licence, and indicate if changes were made. The images or other third party material in this article are included in the article's Creative Commons licence, unless indicated otherwise in a credit line to the material. If material is not included in the article's Creative Commons licence and your intended use is not permitted by statutory regulation or exceeds the permitted use, you will need to obtain permission directly from the copyright holder. To view a copy of this licence, visit http://creativecommons.org/licenses/by/4.0/.

\section{References}

Agassiz, A. (1862). On alternate generation of annelids and the embryology of Autolytus cornutus. Boston Journal of Natural History, 7(3), 384-409.

Aguado, M. T., \& Bleidorn, C. (2010). Conflicting signal within a single gene confounds syllid phylogeny (Syllidae, Annelida). Molecular Phylogenetics and Evolution, 55(3), 1128-1138. https://doi.org/10.1016/j.ympev.2010.01.012

Aguado, M. T., Capa, M., Lago-Barcia, D., Gil, J., Pleijel, F., \& Nygren, A. (2019). Species delimitation in Amblyosyllis (Annelida, Syllidae). PLoS ONE, 14(4), e0214211. https://doi.org/10. 1371/journal.pone.0214211

Aguado, M. T., Glasby, C. J., Schroeder, P. C., Weigert, A., \& Bleidorn, C. (2015a). The making of a branching annelid: An analysis of complete mitochondrial genome and ribosomal data of Ramisyllis multicaudata. Scientific Reports, 5, 12072. https://doi.org/10.1038/srep12072

Aguado, M. T., Murray, A., \& Hutchings, P. (2015b). Syllidae (Annelida: Phyllodocida) from Lizard Island, Great Barrier Reef, Australia. Zootaxa, 4019(1), 035-060. https://doi.org/ 10.11646/zootaxa.4019.1.5

Aguado, M. T., Richter, S., Sontowski, R., Golombek, A., Struck, T. H., \& Bleidorn, C. (2016). Syllidae mitochondrial gene order is unusually variable for Annelida. Gene, 594(1), 89-96. https:// doi.org/10.1016/j.gene.2016.08.050

Aguado, M. T., San Martín, G., \& Siddall, M. E. (2012). Systematics and evolution of syllids (Annelida, Syllidae). Cladistics, 28, 234-250. https://doi.org/10.1111/j.1096-0031.2011.00377.x

Altschul, S. F., Gish, W., Miller, W., Myers, E. W., \& Lipman, D. J. (1990). Basic local alignment search. Journal of Molecular Biology, 215, 403-410. https://doi.org/10.1016/S0022-2836(05) 80360-2

Álvarez-Campos, P., Giribet, G., \& Riesgo, A. (2017). The Syllis gracilis species complex: A molecular approach to a difficult taxonomic problem (Annelida, Syllidae). Molecular Phylogenetics and Evolution, 109, 138-150. https://doi.org/10.1016/j. ympev.2016.12.036

Álvarez-Campos, P., Taboada, S., San Martín, G., Leiva, C., \& Riesgo, A. (2018). Phylogenetic relationships and evolution of reproductive modes within flattened syllids (Annelida, Syllidae) with the description of a new genus and six new species. Invertebrate Systematics, 32, 224-251. https://doi.org/10.1071/IS17011
Augener, H. (1913). Polychaeta I, Errantia. In W. Michaelsen \& R. Hartmeyer (Eds.), Die Fauna Südwest-Australiens. Ergebnisse der Hamburger südwest-australischen Forschungsreise, 1905 (Vol. 4, Issue 5, pp. 65-305). Gustav Fischer. https://doi.org/ $10.1038 / 077051 \mathrm{~b} 0$

Augener, H. (1922). Ueber litorale Polychaeten von Westindien. Sitzungsberichte Der Gesellschaft Naturforschende Freunde Zur Berlin, 3-5, 38-53.

Balavoine, G. (2014). Segment formation in Annelids: Patterns, processes and evolution. International Journal of Developmental Biology, 58, 469-483. https://doi.org/10.1387/ijdb.140148gb

Bastrop, R., Jürss, K., \& Sturmbauer, C. (1998). Cryptic species in a marine polychaete and their independent introduction from North America to Europe. Molecular Biology and Evolution, 15(2), 97-103. https://doi.org/10.1093/oxfordjournals.molbev. a025919

Bely, A. E. (2006). Distribution of segment regeneration ability in the Annelida. Integrative and Comparative Biology, 46(4), 508-518. https://doi.org/10.1093/icb/icj051

Bernt, M., Donath, A., Jühling, F., Externbrink, F., Florentz, C., Fritzsch, G., Pütz, J., Middendorf, M., \& Stadler, P. F. (2012). MITOS: Improved de novo metazoan mitochondrial genome annotation. Molecular Phylogenetics and Evolution, 69(2), 313319. https://doi.org/10.1016/j.ympev.2012.08.023

Bolger, A. M., Lohse, M., \& Usadel, B. (2014). Trimmomatic: A flexible trimmer for Illumina sequence data. Bioinformatics, 30(15), 2114-2120. https://doi.org/10.1093/bioinformatics/btu170

Castresana, J. (2000). Selection of conserved blocks from multiple alignments for their use in phylogenetic analysis. Molecular Biology and Evolution, 17(4), 540-552. https://doi.org/10.1093/ oxfordjournals.molbev.a026334

Cerca, J., Colon, A. G. R., Ferreira, M. S., Ravinet, M., Nowak, M. D., Catchen, J. M., \& Struck, T. H. (2021). Incomplete lineage sorting and ancient admixture, and speciation without morphological change in ghost-worm cryptic species. PeerJ, 9, e10896. https:// doi.org/10.7717/peerj.10896

Cerca, J., Meyer, C., Stateczny, D., Siemon, D., Wegbrod, J., Purschke, G., Dimitrov, D., \& Struck, T. H. (2020). Deceleration of morphological evolution in a cryptic species complex and its link to paleontological stasis. Evolution, 74(1), 116-131. https://doi.org/ 10.1111/evo.13884

Chernomor, O., Von Haeseler, A., \& Minh, B. Q. (2016). Terrace aware data structure for phylogenomic inference from supermatrices. Systematic Biology, 65(6), 997-1008. https://doi.org/10.1093/ sysbio/syw037

Conant, G. C., \& Wolfe, K. H. (2008). GenomeVx: Simple web-based creation of editable circular chromosome maps. Bioinformatics, 24(6), 861-862. https://doi.org/10.1093/bioinformatics/btm598

Crossland, C. (1933). Distribution of the polychaete worm, Syllis ramosa, McIntosh. Nature, 31, 242 (only). https://doi.org/10. $1038 / 131242 \mathrm{a} 0$

Folmer, O., Black, M., Hoeh, W., Lutz, R., \& Vrijenhoek, R. (1994). DNA primers for amplification of mitochondrial cytochrome $\mathrm{c}$ oxidase subunit I from diverse metazoan invertebrates. Molecular Marine Biology and Biotechnology, 3(5), 294-299. https://doi.org/ 10.1371/journal.pone.0013102

Forsskål, P. (1775). Descriptiones animalium, avium, amphibiorum, piscium, insectorum, vermium; quae in itinere orientali observavit Petrus Forskål. Post mortem auctoris edidit Carsten Niebuhr. Ex officina Mölleri.

Franke, H.-D. (1999). Reproduction of the Syllidae (Annelida: Polychaeta). Hydrobiologia, 402(2), 39-55. https://doi.org/10.1023/A: 1003732307286

Glasby, C. J., Schroeder, P. C., \& Aguado, M. T. (2012). Branching out: A remarkable new branching syllid (Annelida) living in a Petrosia sponge (Porifera: Demospongiae). Zoological Journal 
of the Linnean Society, 164, 481-497. https://doi.org/10.1111/j. 1096-3642.2011.00800.x

Grabherr, M. G., Haas, B. J., Yassour, M., Levin, J. Z., Thompson, D., \& a, Amit, I., Adiconis, X., Fan, L., Raychowdhury, R., Zeng, Q., Chen, Z., Mauceli, E., Hacohen, N., Gnirke, A., Rhind, N., di Palma, F., Birren, B. W., Nusbaum, C., Lindblad-Toh, K., ... Regev, A. (2011). Full-length transcriptome assembly from RNA-Seq data without a reference genome. Nature Biotechnology, 29(7), 644-652. https://doi.org/10.1038/nbt.1883

Gray, J. E. (1872). On a new genus of hexaradiate and other sponges discovered in the Philippine Islands by Dr. A.B. Meyer. Annals and Magazine of Natural History Series IV, 10(56), 134-139. https://doi.org/10.1080/00222937208696659

Grube, A. E. (1863). Beschreibung neuer oder wenig bekannter Anneliden. Sechster Beitrag. Archiv Für Naturgeschichte, 29, 37-69. https://doi.org/10.5962/BHL.PART.9306

Gunton, L. M., Kupriyanova, E., \& Alvestad, T. (2020). Two new deep-water species of Ampharetidae (Annelida: Polychaeta) from the eastern australian continental margin. Records of the Australian Museum, 72(4), 101-121. https://doi.org/10.3853/J. 2201-4349.72.2020.1763

Gurevich, A., Saveliev, V., Vyahhi, N., \& Tesler, G. (2013). QUAST: Quality assessment tool for genome assemblies. Bioinformatics, 29(8), 1072-1075. https://doi.org/10.1093/bioinformatics/ btt086

Haas, B. J., Papanicolaou, A., Yassour, M., Grabherr, M., Philip, D., Bowden, J., Couger, M. B., Eccles, D., Li, B., Macmanes, M. D., Ott, M., Orvis, J., \& Pochet, N. (2013). De novo transcript sequence reconstruction from RNA-seq using the Trinity platform for reference generation and analysis. Nature Protocols, 8(8), 1-43. https://doi.org/10.1038/nprot.2013.084

Hall, T. A. (1999). BioEdit: A user-friendly biological sequence alignment editor and analysis program for Windows 95/98/NT. Nucleic Acids Symposium Series, 41, 95-98.

Hartmann-Schröder, G. (1962). Die Polychaeten des Eulitorals. In: Hartmann-Schröder, G. and Gerd Hartmann. Zur Kenntnis des Eulitorals der chilenischen Pazifikküste und der argentinischen Küste Südpatagoniens unter besonderer Berücksichtigung der Polychaeten und Ostracoden. Mitteilungen Aus Dem Hamburgischen Zoologischen Museum Und Institut, 60, 57-270.

Holló, G., \& Novák, M. (2012). The manoeuvrability hypothesis to explain the maintenance of bilateral symmetry in animal evolution. Biology Direct, 7(22), 1-7. https://doi.org/10.1186/ 1745-6150-7-22

Ijima, I. (1898). The genera and species of Rosselidae. Annotationes Zoologicae Japonenses, 2(3), 41-55.

Imajima, M. (1966). The Syllidae (polychaetous annelids) from Japan (IV) syllinae (1). Publications of the Seto Marine Biological Laboratory, 14(3), 219-252. https://doi.org/10.5134/175436

Izuka, A. (1912). The errantiate Polychaeta of Japan. Journal of the College of Science, Imperial University of Tokyo, 30(2), 1-262. https://doi.org/10.1126/science.ns-18.446.109

Jaeckle, W. B., \& Strathmann, R. R. (2013). The anus as a second mouth: Anal suspension feeding by an oral deposit-feeding sea cucumber. Invertebrate Biology, 132(1), 62-68. https://doi.org/ 10.1111/ivb.12009

Johnson, H. P. (1901). The Polychaeta of the Puget Sound region. Proceedings of the Boston Society for Natural History, 29(18), 381-437.

Johnson, H. P. (1902). Collateral budding in annelids of the genus Trypanosyllis. The American Naturalist, 36(424), 295-315. https://doi.org/10.1086/278120

Jumars, P. A., Dorgan, K. M., \& Lindsay, S. M. (2015). Diet of worms emended: An update of polychaete feeding guilds. Annual Review of Marine Science, 7, 497-520. https://doi.org/ 10.1146/annurev-marine-010814-020007
Kalyaanamoorthy, S., Minh, B. Q., Wong, T. K. F., Haeseler, A. Von, \& Jermiin, L. S. (2017). ModelFinder: Fast model selection for accurate phylogenetic estimates. Nature Methods, 14, pages587-589. https://doi.org/10.1038/nmeth.4285

Katoh, K., Rozewicki, J., \& Yamada, K. D. (2017). MAFFT online service: Multiple sequence alignment, interactive sequence choice and visualization. Briefings in Bioinformatics, 20(4), 1160-1166. https://doi.org/10.1093/bib/bbx108

Katoh, K., \& Standley, D. M. (2013). MAFFT multiple sequence alignment software version 7: Improvements in performance and usability. Molecular Biology and Evolution, 30(4), 772-780. https:// doi.org/10.1093/molbev/mst010

Kück, P., \& Longo, G. C. (2014). FASconCAT-G: extensive functions for multiple sequence alignment preparations concerning phylogenetic studies. Frontiers in Zoology, 11(81). https://doi.org/10. 1186/s12983-014-0081-x

Kück, P., \& Meusemann, K. (2010). FASconCAT: Convenient handling of data matrices. Molecular Phylogenetics and Evolution, 56(3), 1115-1118. https://doi.org/10.1016/j.ympev.2010.04.024

Kumar, S., Stecher, G., \& Tamura, K. (2016). MEGA7: Molecular evolutionary genetics analysis version 7.0 for bigger datasets. Molecular Biology and Evolution, 33(7), 1870-1874. https://doi. org/10.1093/molbev/msw054

Kvist, S. (2016). Does a global DNA barcoding gap exist in Annelida? Mitochondrial DNA. Part a, DNA Mapping, Sequencing, and Analysis, 27(3), 2241-2252. https://doi.org/10.3109/19401736. 2014.984166

Langerhans, P. (1879). Die Wurmfauna von Madeira [Part I]. Zeitschrift Für Wissenschaftliche Zoologie, 32(4), 513-592.

Larsson, A. (2014). AliView: A fast and lightweight alignment viewer and editor for large datasets. Bioinformatics, 30(22), 3276-3278. https://doi.org/10.1093/bioinformatics/btu531

Lee, J. (1992). 한 국 산 염주갯지렁이 과(환형동물 운, 다모 강)의 계통분류학 적 연구 [Doctoral dissertation, Ewha Womans University]. Ewha Research Repository. https://dspace.ewha.ac.kr/ handle/2015.oak/194291

Lobo, J., Teixeira, M. A. L., Borges, L. M. S., Ferreira, M. S. G., Hollatz, C., Gomes, P. T., Sousa, R., Ravara, A., Costa, M. H., \& Costa, F. O. (2016). Starting a DNA barcode reference library for shallow water polychaetes from the southern European Atlantic coast. Molecular Ecology Resources, 16(1), 298-313. https://doi. org/10.1111/1755-0998.12441

Madeira, F., Park, Y., \& mi, Lee, J., Buso, N., Gur, T., Madhusoodanan, N., Basutkar, P., Tivey, A. R. N., Potter, S. C., Finn, R. D., \& Lopez, R. (2019). The EMBL-EBI search and sequence analysis tools APIs in 2019. Nucleic Acids Research, 47(W1), W636W641. https://doi.org/10.1093/nar/gkz268

Malmgren, A. J. (1867). Annulata Polychaeta Spetsbergia, Gronlandia, Islandice et Scandinavia. Hactenus Cognita. Ex Officina Frenckelliana.

Martin, D., Aguado, M. T., \& Britayev, T. A. (2009). Review of the symbiotic genus Haplosyllides (Polychaeta: Syllidae), with a description of a new species. Zoological Science, 26(9), 646-655. https://doi.org/10.2108/zsj.26.646

Martin, D., \& Britayev, T. A. (1998). Symbiotic polychaetes: Review of known species. Oceanography and Marine Biology: An Annual Review, 36, 217-340. https://doi.org/10.1201/b12646

Martin, D., \& Britayev, T. A. (2018). Symbiotic polychaetes revisited: An update of the known species and relationships (1998-2017). Oceanography and Marine Biology: An Annual Review, 56, 371448. https://doi.org/10.1201/9780429454455

Martin, D., Britayev, T. A., San Martín, G., \& Gil, J. (2003). Interpopulation variability and character description in the spongeassociated Haplosyllis spongicola complex (Polychaeta: Syllidae). Hydrobiologia, 496, 145-162. https://doi.org/10.1023/A: 1026184529208 
McIntosh, W. C. (1879). On a remarkably branched Syllis dredged by H.M.S. Challenger. Journal of the Linnean Society London, 14, 720-724. https://doi.org/10.1111/j.1096-3642.1879.tb02356.x

McIntosh, W. C. (1885). Report on the Annelida Polychaeta collected by H.M.S. Challenger during the years 1873-1876. Challenger Reports, 12, 189-208. https://doi.org/10.5962/bhl.title.6513

Meyer, M., \& Kircher, M. (2010). Illumina sequencing library preparation for highly multiplexed target capture and sequencing. Cold Spring Harbor Protocols, 5(6). https://doi.org/10.1101/ pdb.prot5448

Miglietta, M. P., Hourdez, S., Cowart, D. A., Schaeffer, S. W., \& Fisher, C. (2010). Species boundaries of Gulf of Mexico vestimentiferans (Polychaeta, Siboglinidae) inferred from mitochondrial genes. Deep-Sea Research Part II: Topical Studies in Oceanography, 57(21-23), 1916-1925. https://doi.org/10.1016/j.dsr2.2010.05. 007

Nguyen, L. T., Schmidt, H. A., Von Haeseler, A., \& Minh, B. Q. (2015). IQ-TREE: A fast and effective stochastic algorithm for estimating maximum-likelihood phylogenies. Molecular Biology and Evolution, 32(1), 268-274. https://doi.org/10.1093/molbev/ msu300

Nygren, A., Parapar, J., Pons, J., Meißner, K., Bakken, T., Kongsrud, J. A., Oug, E., Gaeva, D., Sikorski, A., Johansen, R. A., Hutchings, P. A., Lavesque, N., \& Capa, M. (2018). A mega-cryptic species complex hidden among one of the most common annelids in the north east Atlantic. PLoS ONE, 13(6), e0198356. https://doi.org/ 10.1371/journal.pone. 0198356

Oka, A. (1895). Über die Knospungsweise bei Syllis ramosa. Zoologischer Anzeiger, 18, 462-464.

Okada, Y. K. (1933). Two interesting syllids, with remarks on their asexual reproduction. Mem. College of Sci., Kyoto Imperial University. Ser. B., 8(3), 325-338.

Okada, Y. K. (1937). La stolonisation et les caracteres sexuels du stolon chez les syllidiens polychetes (Études sur les syllidiens III). Japanese Journal of Zoology, 7, 441-490.

Peng, Y., Leung, H. C. M., Yiu, S. M., \& Chin, F. Y. L. (2012). IDBA-UD: A de novo assembler for single-cell and metagenomic sequencing data with highly uneven depth. Bioinformatics, 28(11), 1420-1428. https://doi.org/10.1093/bioinformatics/bts174

Perna, N. T., \& Kocher, T. D. (1995). Patterns of nueleotide composition at fourfold degenerate sites of animal mitochondrial genomes. Jounral of Molecular Evolution, 41, 353-358. https://doi.org/10. 1007/BF00186547

Ponz-Segrelles, G., Bleidorn, C., \& Aguado, M. T. (2018). Expression of vasa, piwi, and nanos during gametogenesis in Typosyllis antoni (Annelida, Syllidae). Evolution \& Development, 20, 132-145. https://doi.org/10.1111/ede.12263

Ponz-Segrelles, G., Glasby, C. J., Helm, C., Beckers, P., Hammel, J. U., Ribeiro, R. P., \& Aguado, M. T. (2021). Integrative anatomical study of the branched annelid Ramisyllis multicaudata (Annelida, Syllidae). Journal of Morphology, 282(6), 900-916. https://doi. org/10.1002/jmor.21356

Prjibelski, A., Antipov, D., Meleshko, D., Lapidus, A., \& Korobeynikov, A. (2020). Using SPAdes De Novo Assembler. Current Protocols in Bioinformatics, 70(1), e102. https://doi.org/10.1002/cpbi.102

Radashevsky, V. I., Pankova, V. V., Neretina, T. V., Stupnikova, A. N., \& Tzetlin, A. B. (2016). Molecular analysis of the Pygospio elegans group of species (Annelida: Spionidae). Zootaxa, 4083(2), 239-250. https://doi.org/10.11646/zootaxa.4083.2.4

Read, G. (2001). Unique branching worm found in New Zealand. Biodiversity Update (NIWA), 4, 1 (only).

Renaud, G., Kircher, M., Stenzel, U., \& Kelso, J. (2013). freeIbis: An efficient basecaller with calibrated quality scores for Illumina sequencers. Bioinformatics, 29(9), 1208-1209. https://doi.org/ 10.1093/bioinformatics/btt117

Renaud, G., Stenzel, U., \& Kelso, J. (2014). LeeHom: Adaptor trimming and merging for Illumina sequencing reads. Nucleic Acids Research, 42(18), e141. https://doi.org/10.1093/nar/gku699

Ribeiro, R. P., Ponz-Segrelles, G., Helm, C., Egger, B., Bleidorn, C., \& Aguado, M. T. (2020). A new species of Syllis including transcriptomic data and an updated phylogeny of Syllinae (Annelida: Syllidae). Marine Biodiversity, 50(31), 16. https://doi.org/10. 1007/s12526-020-01046-y

San Martín, G., \& Aguado, M. T. (2014). Family Syllidae. In A. Schmidt-Rhaesa (Ed.), Handbook of Zoology. Annelida: Polychaetes (pp. 1-68). De Gruyter.

Schroeder, P. C., Aguado, M. T., Malpartida, A., \& Glasby, C. J. (2017). New observations on reproduction in the branching polychaetes, Ramisyllis multicaudata and Syllis ramosa (Annelida: Syllidae: Syllinae). Journal of the Marine Biological Association of the United Kingdom, 97(5), 1167-1175. https://doi.org/ 10.1017/S002531541700039X

Simon, C., Frati, F., Beckenbach, A., Crespi, B., Liu, H., \& Flook, P. (1994). Evolution, weighting, and phylogenetic utility of mitochondrial gene sequences and a compilation of conserved polymerase chain reaction primers. Annals of the Entomological Society of America, 87(6), 651-701. https://doi.org/10.1093/ aesa/87.6.651

Taboada, S., Serra Silva, A., Díez-Vives, C., Neal, L., Cristobo, J., Ríos, P., Hestetun, J. T., Clark, B., Rossi, M. E., Junoy, J., Navarro, J., \& Riesgo, A. (2021). Sleeping with the enemy: Unravelling the symbiotic relationships between the scale worm Neopolynoe chondrocladiae (Annelida: Polynoidae) and its carnivorous sponge hosts. Zoological Journal of the Linnean Society, 193(1), 295-318. https://doi.org/10.1093/zoolinnean/zlaa146

Tang, C. Q., Leasi, F., Obertegger, U., Kieneke, A., Barraclough, T. G., $\&$ Fontaneto, D. (2012). The widely used small subunit $18 \mathrm{~S}$ rDNA molecule greatly underestimates true diversity in biodiversity surveys of the meiofauna. Proceedings of the National Academy of Sciences of the United States of America, 109(40), 16208-16212. https://doi.org/10.1073/pnas.1209160109

Turon, M., Uriz, M. J., \& Martin, D. (2019). Multipartner symbiosis across biological domains: Looking at the eukaryotic associations from a microbial perspective. Msystems, 4(4), 1-14. https://doi. org/10.1128/msystems.00148-19

Vivien, R., Wyler, S., Lafont, M., \& Pawlowski, J. (2015). Molecular barcoding of aquatic oligochaetes: Implications for biomonitoring. PLoS ONE, 10(4), e0125485. https://doi.org/10.1371/journal.pone. 0125485

Xia, X. (2018). DAMBE7: New and improved tools for data analysis in molecular biology and evolution. Molecular Biology and Evolution, 35(6), 1550-1552. https://doi.org/10.1093/molbev/msy073

Zattara, E. E., \& Weisblat, D. A. (2020). Cellular and molecular mechanisms of segmentation in Annelida: An open question. In A. D. Chipman (Ed.), Cellular processes in segmentation (pp. 71-97). Taylor \& Francis.

Zhang, Z., Schwartz, S., Wagner, L., \& Miller, W. (2000). A greedy algorithm for aligning DNA sequences. Journal of Computational Biology, 7(1-2), 203-214. https://doi.org/10.1089/ 10665270050081478

Publisher's Note Springer Nature remains neutral with regard to jurisdictional claims in published maps and institutional affiliations. 